\title{
Barbados: 2009 Article IV Consultation-Staff Report; and Public Information Notice on its Consideration by the Executive Board
}

Under Article IV of the IMF's Articles of Agreement, the IMF holds bilateral discussions with members, usually every year. In the context of the 2009 Article IV consultation with Barbados, the following documents have been released and are included in this package:

- $\quad$ The staff report for the 2009 Article IV consultation, prepared by a staff team of the IMF, following discussions that ended on July 17, 2009, with the officials of Barbados on economic developments and policies. Based on information available at the time of these discussions, the staff report was completed on September 2, 2009. The views expressed in the staff report are those of the staff team and do not necessarily reflect the views of the Executive Board of the IMF.

- $\quad$ A Public Information Notice (PIN) summarizing the views of the Executive Board as expressed during its September 10, 2009 consideration of the staff report that concluded the Article IV consultation.

The policy of publication of staff reports and other documents allows for the deletion of market-sensitive information.

$$
\begin{gathered}
\text { Copies of this report are available to the public from } \\
\text { International Monetary Fund • Publication Services } \\
70019^{\text {th }} \text { Street, N.W. • Washington, D.C. 20431 } \\
\text { Telephone: (202) 623-7430 • Telefax: (202) 623-7201 } \\
\text { E-mail: publications@imf.org Internet: http://www.imf.org }
\end{gathered}
$$

Price: $\$ 18.00$ a copy

\section{International Monetary Fund Washington, D.C.}


INTERNATIONAL MONETARY FUND

\title{
BARBADOS
}

\section{Staff Report for the 2009 Article IV Consultation}

\author{
Prepared by the Staff Representatives for the 2009 Article IV Consultation \\ with Barbados
}

Approved by Gilbert Terrier and David Marston

September 2, 2009

- Background. After barely growing in 2008, the Barbados economy is expected to contract by 3 percent in 2009, buffeted by the global recession. Price pressures have abated, and domestic demand has slowed. International reserves declined in recent months, reflecting lower tourism receipts and private capital inflows but were recently boosted by a successful international bond placement. Widening fiscal deficits in recent years led to an increase in public debt to 106 percent of GDP at end-2008.

- Focus of consultation. Discussions focused on the impact of the global recession on Barbados and the options and priorities to weather the crisis and ensure medium-term macroeconomic stability and growth. The mission recommended early tightening of the fiscal stance within a credible medium-term fiscal consolidation framework.

- Authorities' views. The authorities are reluctant to tighten fiscal policy, on the grounds that this would deepen the recession and weaken confidence. They are confident that they can secure foreign financing to cover the budget shortfall and stabilize reserves.

- Exchange system. The Barbados dollar has been pegged to the U.S. dollar at the rate of BDS $\$ 2.00=\mathrm{US} \$ 1.00$ since 1975. Barbados has accepted the obligations of Article VIII, Sections 2, 3, and 4, and maintains an exchange system free of restrictions on current account transactions. While at end-2008 the real effective exchange rate was close to its estimated equilibrium, efforts should be intensified to address the risks to external stability from large fiscal imbalances.

- Mission. The team that visited Bridgetown during July 10-17 comprised Trevor Alleyne (head), Gamal El-Masry, Usman Khosa, and Carla Macario (all WHD). Michael Horgan (Executive Director) and Pierre St-Amant (OED, Senior Advisor) participated in the concluding discussions. The team met with Prime Minister David Thompson; Minister of State (Finance) Senator Darcy Boyce; Central Bank Governor Dr. Marion Williams; other senior government officials; and representatives of the private sector and labor. 
I. Background and Economic Outlook .3

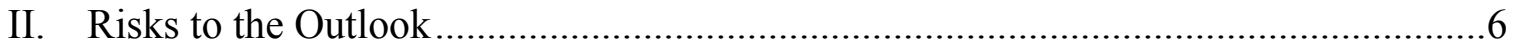

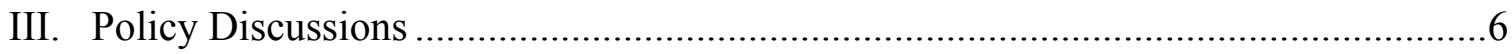

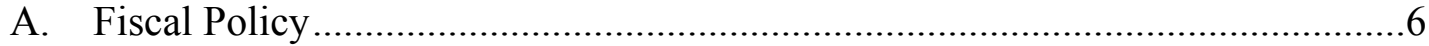

B. Monetary and Exchange Rate Policies .................................................. 9

C. Financial Sector Policies............................................................................ 9

D. Statistical Issues ..................................................................................... 11

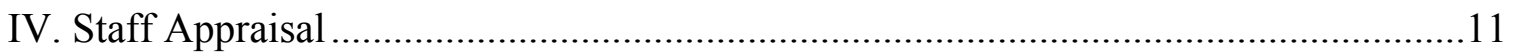

Boxes

1. Exchange Rate Assessment......................................................................................

2. Outlook for the Offshore Financial Sector.......................................................

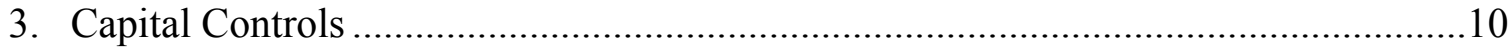

Figures

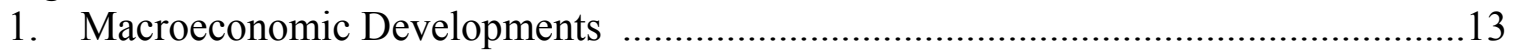

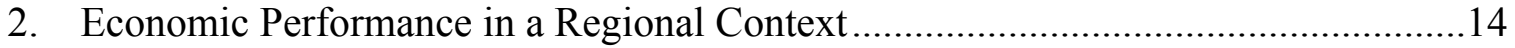

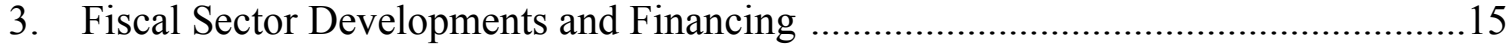

Tables

1. Selected Economic, Financial, and Social Indicators (Baseline)..............................16

2. Nonfinancial Public Sector Operations (Baseline) ................................................ 17

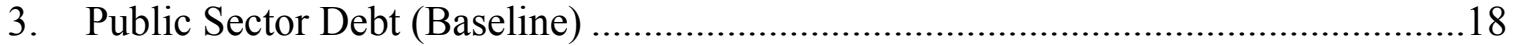

4. Balance of Payments (Baseline) ............................................................................

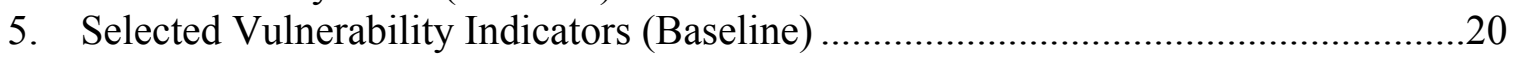

Appendices

I. Illustrative Scenarios and Debt Sustainability Analyses .....................................21

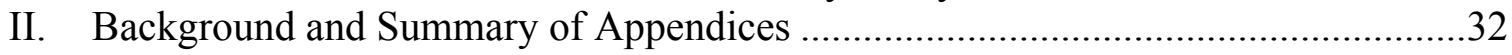

Appendix Figures

1. Public Debt Sustainability: Bound Tests (Baseline scenario)................................25

2. External Debt Sustainability: Bound Tests (Baseline scenario) ...............................27

3. Public Debt Sustainability: Bound Tests (Adjustment scenario).............................29

4. External Debt Sustainability: Bound Tests (Adjustment scenario) ...........................31

Appendix Tables

1. Public Sector Debt Sustainability Framework, 2004-14 (Baseline scenario) ..........24

2. External Debt Sustainability Framework, 2004-14(Baseline scenario) ....................26

3. Public Sector Debt Sustainability Framework, 2004-14 (Adjustment scenario) ......28

4. External Debt Sustainability Framework, 2004-14(Adjustment scenario) ..............30 


\section{BACKGROUND AND ECONOMIC OUTLOOK}

1. Barbados has strong public and private institutions and benefits from high political and social stability. The country has some of the highest social and competitiveness indicators in the region and enjoys investment-grade rating on its sovereign bonds. Its low crime level, welleducated work force, reliable infrastructure, and attractive natural setting have helped make it a leading destination for high-end tourism and a prime location for offshore financial services.

\begin{tabular}{|c|c|c|c|}
\hline & Barbados & Jamaica & $\begin{array}{r}\text { Trinidad \& } \\
\text { Tobago }\end{array}$ \\
\hline \multicolumn{4}{|l|}{ Economic indicators } \\
\hline GDP per capita (USD 2008) & 13,328 & 5,335 & 19,012 \\
\hline S\&P sovereign rating (forex long-term debt) & BBB & $\mathrm{CCC}+$ & A \\
\hline Moody's sovereign (forex senior unsecured) & Baa2 & B2 & Baa1 \\
\hline \multicolumn{4}{|l|}{ Social indicators } \\
\hline Human Development Index (UNDP, rank) & 37 & 87 & 57 \\
\hline Health and Primary Education Index (WEF, rank) & 10 & 77 & 72 \\
\hline \multicolumn{4}{|l|}{ Business climate } \\
\hline Global Competitiveness Index (WEF, rank) & 47 & 86 & 92 \\
\hline Business Sophistication Index (WEF, rank) & 51 & 69 & 73 \\
\hline Regulatory Quality (WB, percentile) & 74.4 & 63.8 & 70.5 \\
\hline \multicolumn{4}{|l|}{ Political indicators } \\
\hline Corruption Perception Index (TI, rank) & 22 & 96 & 72 \\
\hline Political Stability (WB, percentile) & 86.6 & 34.9 & 47.8 \\
\hline Rule of Law (WB, percentile) & 88.5 & 39.2 & 48.8 \\
\hline
\end{tabular}

2. The global recession is severely affecting the Barbadian economy. After barely growing ( 0.2 percent) in 2008, real GDP is estimated to have declined by 3 percent $(y / y)$ in the first half of 2009 (Figure 1). Similar to its Caribbean neighbors, stay-over tourist arrivals in Barbados fell thus far in 2009 by 81/2 percent (Figure 2), tourism receipts dropped by more than 11 percent, and construction declined by $4 \frac{1}{2}$ percent, affected by cancelled or delayed tourism-related projects. The unemployment rate rose from 7.9 percent in 2008Q1 to 10.1 percent in 2009Q1, its highest level since 2003. A recovery in tourism will likely have to wait for a resumption in employment growth in advanced countries. Accordingly, output is expected to contract by 3 percent in 2009 and to remain virtually flat in 2010, while the unemployment rate is likely to increase further.

3. Balance of payments pressures have increased, despite a narrowing in the current account deficit. The external current account deficit is projected to narrow from $10 \frac{1}{2}$ percent in 2008 to $5 \frac{1}{4}$ percent of GDP in 2009, reflecting a sharp contraction in imports. In the first semester of 2009, a reversal of private capital flows led to net capital outflows. Thus, despite a 30 percent fall in imports, international reserves declined by about US\$50 million, after a drop of almost US\$100 million in 2008. In the second half of 2009, foreign reserves will be boosted by the SDR allocations (around US $\$ 90$ million) and the successful placement in August of a US\$120 million government bond abroad.

4. Based on current policies, in FY 2009/10, the non-financial public sector (NFPS) deficit would widen to $81 / 2$ percent, with public debt rising to 115 percent of GDP by year-end. Reflecting a steady relaxation of the fiscal stance in recent years, the overall balance of the nonfinancial sector shifted from a small surplus in FY 2004/05 (April to March) to a deficit of 71/2 percent of GDP in FY 2008/09. In the first quarter of this fiscal year, tax collections declined by 9.3 percent year-on-year. In June, Standard and Poor's downgraded Barbados's foreign currency rating from $\mathrm{BBB}+$ to $\mathrm{BBB}$, with stable outlook, citing the country's high debt, weak outlook, and difficult fiscal challenges.

\section{As part of the FY 2009/10 budget, the government announced a number of} countercyclical fiscal measures. These included: (i) public loans, grants, and guarantees to encourage the renovation of tourism-related facilities; (ii) new public capital projects; and (iii) an employment stabilization scheme under which employers would be allowed to defer 
for one year their contribution to the National Insurance Scheme (NIS). At the same time, the government took important steps to place public enterprises on a more solid footing. In October 2008, it introduced a new pricing mechanism for domestic fuel prices, to bring them in line with international prices and, in July 2009, raised utility rates for water and wastewater services by an average of 60 percent - the first such rate increase in 20 years.

6. At end-March 2009, twelve-month broad money growth was flat. Although yearon-year credit growth remains positive (71/2 percent in April) it has decelerated sharply in recent months. Twelve-month inflation, which had peaked at 11.2 percent $(y / y)$ in September 2008, fell to 3.8 percent in April 2009, and is projected at 3-4 percent by year-end. With declining inflation pressures, the Central Bank of Barbados (CBB) has eased monetary conditions, gradually lowering the minimum deposit rate from 51/4 percent in November 2007 to $2 \frac{1}{2}$ percent in August 2009. In early July, it also reduced the reserve requirement on foreign currency deposits from 6 percent to 4 percent.

\begin{tabular}{|c|c|c|c|c|c|}
\hline \multicolumn{6}{|c|}{$\begin{array}{l}\text { Barbados: Main Economic Indicators } \\
\text { (In percent of GDP, unless otherwise indicated) }\end{array}$} \\
\hline & \multirow[b]{2}{*}{2006} & \multirow[b]{2}{*}{2007} & \multirow{2}{*}{$\begin{array}{l}\text { Prel. } \\
2008 \\
\end{array}$} & \multicolumn{2}{|c|}{ Proj. } \\
\hline & & & & 2009 & 2010 \\
\hline Real GDP (annual percent change) & 3.2 & 3.4 & 0.2 & -3.0 & 0.0 \\
\hline $\mathrm{CPI}$ inflation (average in percent) & 7.3 & 4.0 & 8.1 & 3.5 & 5.2 \\
\hline External current account balance & -8.4 & -5.4 & -10.5 & -5.2 & -5.9 \\
\hline Gross international reserves (in months of imports of G\&S) 1/ & 3.3 & 4.0 & 3.3 & 4.2 & 3.4 \\
\hline Nonfinancial public sector overall balance & -5.3 & -8.0 & -7.6 & -8.4 & -7.1 \\
\hline Central government balance & -3.2 & -5.7 & -6.3 & -8.0 & -8.9 \\
\hline National Insurance Scheme & 4.1 & 3.7 & 3.4 & 1.5 & 3.3 \\
\hline Public enterprises & -1.4 & -2.1 & -2.1 & -1.5 & -1.5 \\
\hline Off-budget activities & -4.9 & -3.9 & -2.6 & -0.5 & 0.0 \\
\hline
\end{tabular}

7. Estimates of the equilibrium real effective exchange rate suggest that, as at end2008, the actual rate was close to equilibrium (Box 1). Nevertheless, there remain significant downside risks to external sustainability, in particular, related to the large fiscal imbalances. On current policies, the external current account deficit is projected at about $5 \frac{1}{2}$ percent of GDP over the medium term. However, FDI inflows, which have traditionally financed a significant part of the deficit, would remain subdued. In the absence of corrective measures, reserves are projected to decline to close to two months of imports over the medium term, which could lead to pressures on the currency peg. 


\section{Box 1. Barbados: Exchange Rate Assessment}

Barbados's exchange rate peg has been a very effective nominal anchor. It has provided a long period of nominal exchange rate and price stability, which have had positive effects on investment and growth.

\section{Indicators do not point to a competitiveness} problem. Tourism receipts displayed robust doubledigit growth rates and increased market share during 2005-07, i.e., until the cyclical decline in 2008, which largely reflects a collapse in external demand. Similarly, the country's placement on the OECD's "White List" for international tax jurisdictions (the only such country in the Caribbean) also bodes well for sustained offshore business activity.

\section{Results from the estimation of the equilibrium real effective exchange rate suggest that the actual rate is close to its equilibrium level. The method} relies on a panel regression of actual exchange rates

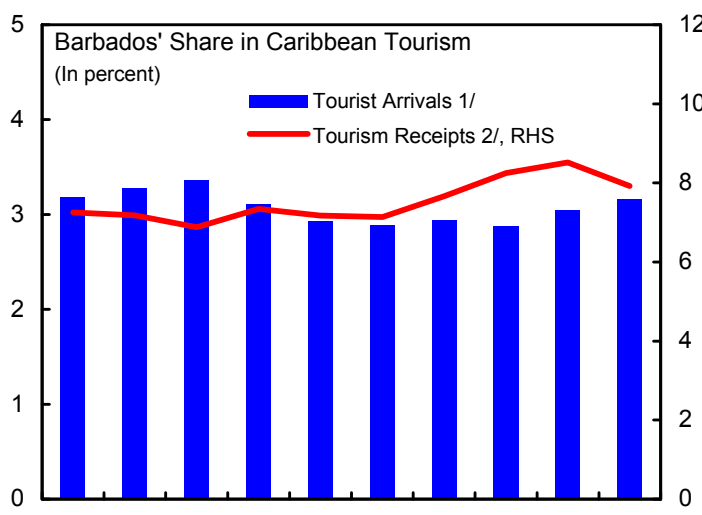

2000200120022003200420052006200720082009 Sources: Caribbean Tourism Organization; country authorities; and Fund staff estimates

1/ Tourism arrivals data through March 2009

$2 /$ The share in receipts is based on a smaller comparator market, including the Bahamas, the Dominican Republic, Jamaica, and the ECCU countries, which together with Barbados account for about half of Caribbean tourist arrivals. on a set of fundamentals, using a sample of tourism-dependent countries in the Caribbean. Barbados's actual exchange rate is almost identical to its estimated equilibrium level, as at end-2008. Nevertheless, there are some downside risks to external sustainability, in particular, related to the large fiscal deficits and the consequent pressure on aggregate demand. In the absence of corrective measures, over the medium term, the external current account deficit is projected at around 56 percent of GDP and international reserves would decline to close to two months of imports, reflecting reduced access to foreign financing.
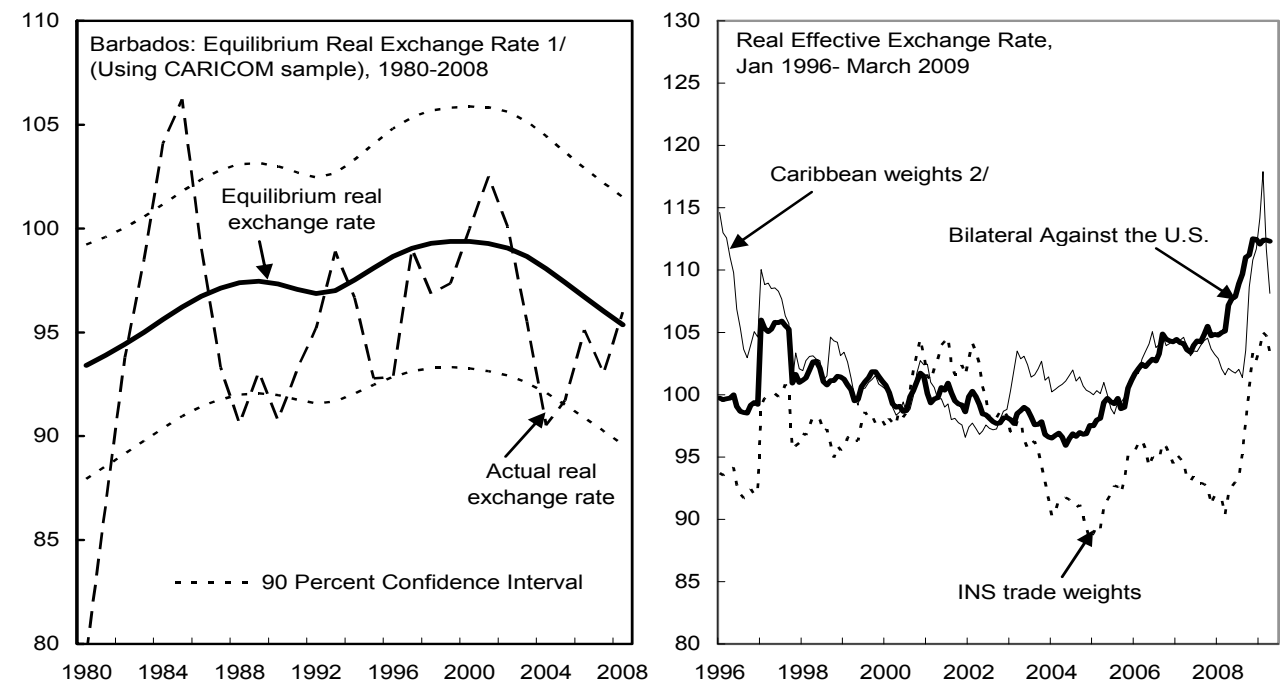

1/E. Pineda, P. Cashin, and Y. Sun, "Assessing Exchange Rate Competitiveness in the Eastern Caribbean Currency Union," IMF Working Paper 09/78.

2/ Weighted by main competitors in the Caribbean tourism market in 2007 (The Bahamas, Belize, Cancun, Dominica, Dominican Republic, Grenada, Guyana, Jamaica, St. Lucia, St. Vincent and The Grenadines, and Trinidad and Tobago). 


\section{RISKS TO THE OUTLOOK}

8. At this stage, risks to the economic outlook are mainly tilted to the downside, arising largely from a protracted recession or anemic recovery in advanced economies. In addition, there is a risk that, at least in the near term, FDI and other private capital inflows to the Caribbean region will not recover to pre-crisis levels. ${ }^{1}$ This would prolong the country's recession and increase pressures on international reserves and the public finances. Moreover, the outlook for the offshore financial sector may be uncertain, particularly if significant changes were to be introduced in the Canadian and U.S. tax regulations governing their companies' overseas operations (Box 2). Sharper-than-projected increases in world oil prices could also place the BOP under strain and reignite inflation pressures. The country's commitment to the fixed exchange rate - both to the regime and to the nominal level vis-àvis the U.S. dollar puts all the burden of adjustment on contractionary domestic policies.

9. There are also important fiscal financing risks. While there appears to be sufficient financing available for the current fiscal year, the outlook for FY 2010/11 and beyond is less certain. There is a risk that, in the context of lower capital inflows, the borrowing requirements of the public sector could crowd out credit to the private sector or lead to reliance on central bank financing. There is also a heightened risk that some public sector entities may no longer be able to service government-guaranteed loans, thus forcing the government to assume and service those loans. Finally, the still uncertain fate of CLICOBarbados (see below) might entail additional budgetary costs not yet reflected in the current fiscal projections.

\section{Policy Discussions}

\section{A. Fiscal Policy}

\section{The mission encouraged the authorities to aim for a lower fiscal deficit in}

FY 2009/10. Given uncertainties about the strength of the global recovery and the normalization of capital flows, the mission cautioned the authorities that large fiscal deficits and declining reserves could result in a sudden and sharp deterioration in investor confidence. Early fiscal action was therefore needed to reduce fiscal financing risks, support the balance of payments, and begin the process of medium-term fiscal consolidation. To this end, it recommended that the authorities seek expenditure savings of about 1 percent of GDP in FY 2009/10, in an effort to keep the overall deficit at around the same level as last year.

\section{The authorities did not favor further tightening the fiscal stance at this stage.}

They noted that their commitment to fiscal prudence was evidenced by the recent tariff adjustment for utilities and expressed concern that fiscal contraction, at a time of declining output, would choke the economy and further weaken confidence. They maintained that their strategy would center on seeking external funding, principally from multilateral institutions,

\footnotetext{
${ }^{1}$ The baseline projections assume a modest recovery in private capital flows, beginning in the second half of 2009 , based on an early resumption of some hotel construction projects.
} 


\section{Box 2. Barbados: Outlook for the Offshore Financial Sector}

The global financial crisis has significantly depressed revenues and profits in Barbados's offshore financial sector, leading to lower corporate tax collections. Even as signs of a global economic recovery emerge, the outlook for the sector is clouded by downside risks stemming from regulatory actions in source markets and increased competition from other offshore centers.

The international business sector is a major contributor to the economy of Barbados. The sector accounts for about two-thirds of corporate tax revenues, employs over 3,500 people, mostly in high-skill jobs, and serves as a magnet for tourism, foreign exchange, and technical know-how. Canada and the United States, with whom Barbados has double taxation avoidance treaties (DTATs), are the most important source markets for activity in the sector.

The current financial crisis has led to a decrease in overall activity in the sector. In recent months, offshore companies have experienced a steep fall in revenues and profits. Although businesses in the sector differ in size and activity, their close linkages to financial institutions and markets in advanced economies have made them susceptible to the global financial crisis.

\begin{tabular}{lr}
\multicolumn{2}{c}{ Barbados: Active International Businesses } \\
\hline & end 2007 \\
\hline Int' Business Companies (IBCs) & 2488 \\
Societies with Restricted Liability & 417 \\
Exempt Insurance Companies & 164 \\
Qualifying Insurance Companies & 55 \\
Offshore Banks & 56 \\
Foreign Sales Corporations & 54 \\
\hline Source: Barbados International Business Association
\end{tabular}

The offshore sector could be adversely affected by changes in U.S. and Canadian tax policy and regulations. Following the report of the Advisory Panel on Canada's System of International Taxation in December 2008, Canada has begun a process of entering into a number of new DTATs, including with some of Barbados's competitors in the region. This would eliminate or at least reduce certain tax advantages that Canadian companies enjoy in Barbados. Also, the United States has proposed new regulations that would limit tax arbitrage opportunities that Barbados offers to U.S. companies.

The authorities should quickly adapt to any changes in international tax regulations. Notwithstanding uncertainties, a sudden downward shift to the business outlook is possible, if certain aspects of the U.S. proposals become law, or if Europe introduces similar curbs on international taxation. That said, Barbados's reputation as a well-managed and developed jurisdiction with a highly educated workforce, together with its placement on the OECD "white list", puts it in a strong position vis-à-vis its competitors. ${ }^{1 /}$

\footnotetext{
1/ On April 2, 2009, the OECD published a scorecard of jurisdictions and their progress towards implementing internationally agreed tax standard. Barbados was placed on the "white list," leaving centers such as Switzerland, Singapore, and Luxemburg on the "grey list". Since then, many jurisdictions have signed tax information exchange agreements with other members and have graduated to the "white list."
} 
to cover the financing needs in the near term, while preparing to implement a strong fiscal adjustment program in the period ahead.

\section{Some uncertainty persists with respect to the financing of the fiscal deficit next}

year. The mission supported the government's efforts to intensify its engagement with multilateral institutions. It agreed that accessing liquidity support facilities and policy-based lending from multilaterals could provide an important buffer against external shocks in the current global environment. It also recommended expediting administrative procedures in order to ensure the rapid disbursement of existing project loans. ${ }^{2}$ It encouraged the authorities to save the proceeds from the US\$120 million foreign bond, with a view to prefinancing a large amortization payment (US\$100 million) due in June 2010. The mission also cautioned the authorities that, absent a significant reduction in the deficit, its financing could be a challenge for next fiscal year and beyond.

\section{The mission noted that there was a risk that, under current policies, public debt} would gradually grow to unsustainable levels (Appendix 1). It recommended that the authorities articulate, as soon as possible, a medium-term fiscal consolidation plan to put the public debt ratio on a clear downward path, once the economy recovers. To this end, it discussed with the authorities an illustrative fiscal adjustment scenario, which would stabilize and subsequently bring down the debt ratio over the medium term. Improved confidence would boost private investment, resulting in higher growth. The mission encouraged the authorities to consider a number of possible fiscal measures, including continued wage moderation, prioritization of capital projects, improvements in the tax regime, and streamlining the operations of state-owned enterprises, in particular the Transport Board and the Barbados Agricultural Management Company.

Possible Fiscal Measures
(Potential savings in percent of GDP)
- Continue to moderate wages to bring down the
central government wage bill to about
10 percent of GDP over five years (1 percent);
- Reverse the large expansion of expenditure in
goods and services ( $2-21 / 4$ percent);
- Prioritize and reduce capital outlays across the
public sector ( $1 / 2-1$ percent);
- Streamline the operations of state-owned
enterprises, and adjust prices for utilities and
other public services ( $2 \frac{1}{2}-3$ percent);
- Improve tax administration and broaden the tax
base ( $1 / 2$ percent);
- Raise the VAT rate by $1-2$ percentage points
( $3 / 4-11 / 2$ percent); and
- Sell government assets

\section{The authorities emphasized their commitment to substantially reduce the fiscal} deficit over the medium term and broadly agreed with these measures. They agreed that a credible medium-term fiscal consolidation strategy was needed and indicated that they had begun its preparation, including with plans for a comprehensive tax reform, which would be designed with support from CARTAC. To reduce spending, the authorities are contemplating a reduction in implicit subsidies for natural gas deliveries and negotiated wage settlements. In this context, the mission noted that Barbados's social partnership —a tripartite framework of high-level consultation between government, business, and trade unions - has proven to be a reliable institutional structure to reach social consensus, particularly on tough policy choices.

\footnotetext{
${ }^{2}$ In a number of cases, the government had completed and fully paid expenses associated with foreign-financed projects, but not yet completed administrative requirements for reimbursement.
} 


\section{B. Monetary and Exchange Rate Policies}

15. The mission cautioned that further monetary policy easing would need to be consistent with maintaining an adequate level of reserves. It pointed out that, at $2 \frac{1}{2}$ percent, the minimum deposit rate remains negative in real terms. Given the decline in international reserves and the authorities' commitment to the exchange rate peg, the scope for further easing appears very limited. The mission recognized that existing capital controls provided the country with some protection against disruptive and volatile capital flows (Box 3). However, it noted that capital flows had turned negative during the first half of 2009 and advised the authorities to monitor developments carefully before adopting any further monetary accommodation.

\section{The authorities indicated that recent cuts in the minimum deposit rate were} consistent with protecting foreign reserves. They noted that interest rates in Barbados remained higher than in industrialized countries and explained that their actions were not aimed at stimulating bank credit but at alleviating interest costs to borrowers. They expected that the cuts would reduce the risks of credit default, at a time when businesses were suffering from lower earnings.

\section{The authorities reaffirmed their strong commitment to the current exchange} rate peg. The fixed peg to the U.S. dollar has been an effective nominal anchor since its establishment in 1975, providing price stability with a positive effect on investment and growth. Staff noted that various indicators suggest that the exchange rate is close to its equilibrium level. However, current global shocks have put strains on the country's economy. Staff noted that there is a risk that pressures on the currency could emerge if private capital inflows were to remain weak, while public debt continued to rise in the context of persistent large fiscal deficit. Staff also noted that, over the medium term, possible changes in tax regulations abroad could adversely affect Barbados's offshore financial sector, which has been an important source of foreign exchange in the past decade.

\section{Financial Sector Policies}

\section{Barbados's banks, which are predominantly Canadian owned, appear well}

capitalized. Thus far, they have not suffered from the turmoil in international financial markets. While prudential indicators remain favorable, the mission advised the authorities to carefully monitor the incipient rise in nonperforming loans, notwithstanding their relatively low level. It also encouraged them to enhance their stress-testing capacity in order to carry out regular monitoring and assessment of macro-financial risks to the banking

\begin{tabular}{|c|c|c|c|c|}
\hline \multicolumn{5}{|c|}{$\begin{array}{l}\text { Barbados: Financial Soundness Indicators, 2006-09 1/ } \\
\text { (In percent) }\end{array}$} \\
\hline & 2006 & 2007 & 2008 & Mar-09 \\
\hline Capital adequacy ratio 2/ & 12.3 & 14.4 & 13.9 & 16.9 \\
\hline NPLs to total loans & 4.5 & 2.9 & 3.4 & 3.3 \\
\hline Provision for loan loss to total loans & 0.7 & 0.7 & 1.0 & 1.2 \\
\hline Return on assets & 2.7 & 2.5 & 2.2 & 0.8 \\
\hline Credit to the private sector, growth 3 / & 13.2 & 6.4 & 11.1 & 7.4 \\
\hline Liquid assets to total assets & 7.4 & 10.7 & 12.2 & 9.6 \\
\hline $\begin{array}{l}\text { Sources: Central Bank of Barbados; and F } \\
\text { 1/ Onshore banking system } \\
\text { 2/ Does not include local branches of forei } \\
\text { 3/ April } 2009\end{array}$ & $\begin{array}{l}\text { nd staff } \\
\text { banks }\end{array}$ & imates. & & \\
\hline
\end{tabular}




\section{Box 3. Barbados: Capital Controls}

The Central Bank of Barbados (CBB) maintains restrictions on capital flows, although these have been implemented liberally. The goal is to protect monetary and financial stability, strengthen the effectiveness of monetary policy, and manage pressures on the peg. In the mid-1990s, however, in line with Barbados's commitments under the CARICOM Single Market and Economy, some controls were lifted. These included granting commercial banks the authority to approve a number of capital transactions, which had previously required prior approval by the CBB. Approval by the CBB is, however, still required for a range of non-CARICOM capital account transactions, including the following:

- Direct investment. The CBB maintains controls on both inward and outward (non-CARICOM) investments but has delegated authority to commercial banks to approve the liquidation of unlisted equity investments in Barbados up to the amount registered with the CBB.

- Real estate. The CBB maintains controls on purchases of real estate abroad by residents, and purchases of real estate in Barbados by nonresidents. In September 2007, the authorities relaxed restrictions on remittance of the proceeds from the sale of real estate in Barbados involving transactions between two or more nonresidents and settled through their respective accounts abroad.

- Capital and money market instruments. Transactions involving the sale and purchase of nonCARICOM securities by residents require CBB approval. Earnings on securities and other money market instruments purchased abroad by residents must be surrendered to commercial banks.

- Financial sector provisions. Commercial banks require CBB approval to borrow abroad to finance their domestic operations and are required to surrender 25 percent of their foreign currency borrowings to the CBB.

system, and the authorities concurred. The mission advised the authorities to pause with the implementation of certain Basel II standards, particularly as they relate to self regulation by commercial banks. It commended the authorities for moving ahead with the implementation of the 2008 FSAP Update recommendations. These steps include new legislation to strengthen regulations on large bank exposures, loan classification, provisioning, and lending to related parties, which the authorities expect to be approved by early 2010 .

\section{The mission welcomed moves for closer regional cooperation in bank}

supervision. Given the integration of the region's financial system, the mission welcomed the signing of various memoranda of understanding, and strengthened cooperation with the Canadian and Trinidadian supervisors on cross-border activities of bank conglomerates.

\section{The mission encouraged the authorities to continue efforts to improve the} regulatory and supervisory framework of the nonbank financial sector. It stressed the importance, in the context of the planned establishment of the Financial Services Commission next year, of taking steps to strengthen its technical capacity. The authorities 
agreed, and to this end, have requested technical assistance from CARTAC to assess and improve the effectiveness of insurance supervision.

21. Decisive action will be needed to resolve the problems of CLICO-Barbados and prevent large losses to the public finances. The government has taken steps to address the contagion problems affecting CLICO-Barbados and its subsidiaries from its Trinidadian parent company, Colonial Life Financial. In particular, earlier this year, the central bank deposited US\$5 million into CLICO-Barbados's mortgage subsidiary, and gave it access to a special credit window. At the same time, the government is trying to facilitate an orderly takeover of CLICO-Barbados and its subsidiaries by other viable financial entities, without recourse to public funds. The issues involved are complex, due to some illiquid assets and a significant shortfall (about 3 percent of GDP) in the statutory fund of the life-insurance subsidiary. In this context, the mission encouraged the authorities to develop contingency plans that could be quickly implemented in the event that the current approach is unsuccessful, to mitigate the potential impact on the already high public debt, on financial sector soundness and on investor confidence. The authorities expressed confidence that their efforts would result in a positive outcome and explained that a number of local entities had already entered firm bids to acquire one of CLICO-Barbados subsidiaries.

\section{Statistical Issues}

22. The mission welcomed the completion of a CARTAC-sponsored technical study aimed at improving the coverage, and revising the series, of current GDP. This study implies that 2007 nominal GDP was underestimated by about 15 percent, mainly due to under-coverage of the financial and tourism sectors. While the timing has yet to be determined, the mission recommended that the authorities publish the revised data as soon as possible, as the corrected nominal GDP data would have important implications for a number of macroeconomic indicators. It also encouraged the authorities to seek additional technical assistance in order to revise GDP series at constant prices, which still rely on the economic structure of 1974 as a base year.

\section{Staff Appraisal}

23. Barbados is facing a severe economic recession. Output is contracting, as the global financial crisis has depressed tourism, brought FDI to a sudden stop, and weakened public finances. Consequently, unemployment has risen to double-digit level, and international reserves have declined. While the underlying balance of payments is expected to remain weak, international reserves are expected to increase marginally in 2009 , on account of the SDR allocations and the large government bond issue abroad.

24. The authorities are committed to maintaining the fixed exchange-rate peg. The longstanding peg to the U.S. dollar has been an effective nominal anchor, providing price stability with a positive effect on investment and growth. While various indicators suggest that the actual exchange rate is close to its equilibrium level, the current global shocks have put strains on the country's economy. In addition, possible changes in tax regulations abroad 
could adversely affect Barbados's offshore financial sector, which is an important source of foreign exchange.

\section{The authorities are encouraged to develop a credible medium-term fiscal} adjustment plan and start with its implementation, as soon as possible. If left unchecked, the large fiscal deficits, combined with an uncertain foreign financing outlook, could result in a sudden and sharp deterioration in investor confidence. A concerted adjustment effort is, therefore, crucial to countering such a risk, by reducing fiscal financing needs, supporting the balance of payments, and placing public debt on a firm downward path. This would also enhance growth, including by enhancing confidence and attracting higher investment. To this end, the authorities will need to commit early on to decisive fiscal measures, particularly in the area of expenditure restraint. It will also be important to develop contingency plans, in the event that the economic recovery is delayed and fiscal pressures persist. Barbados is, however, well placed to take such bold action, given its established social partnership that has a proven track record of reaching social consensus, particularly at difficult times.

\section{Monetary policy should be geared to ensuring price stability and protecting}

foreign reserves. The existing capital controls give the country some protection against disruptive and volatile capital movements, thereby providing the authorities some room to independently set interest rates. Given the recent decline in foreign reserves, the authorities are encouraged, in the context of their strong commitment to the peg, to monitor developments closely before easing monetary policy further.

27. Barbados's banks appear to be well capitalized. Prudential indicators remain favorable, and the mission advised the authorities to carefully monitor the incipient rise in nonperforming loans, although they were still at a relatively low level. On banking supervision, the authorities should review the implementation of certain Basel II standards, particularly regarding the self regulation by commercial banks. The authorities are commended for moving ahead with implementing the recommendations of the 2008 FSAP Update. Quick and decisive action should be taken to resolve the problems of CLICOBarbados and prevent large losses to the public finances. There is also a need to develop contingency plans, should the current approach of selling CLICO-Barbados's subsidiaries to private investors prove unsuccessful, to mitigate the impact on the public finances, and protect the financial system and investor confidence.

\section{It is recommended that the next Article IV consultation be held on the standard} 12-month cycle. 
Figure 1. Barbados: Macroeconomic Developments, 2000-09

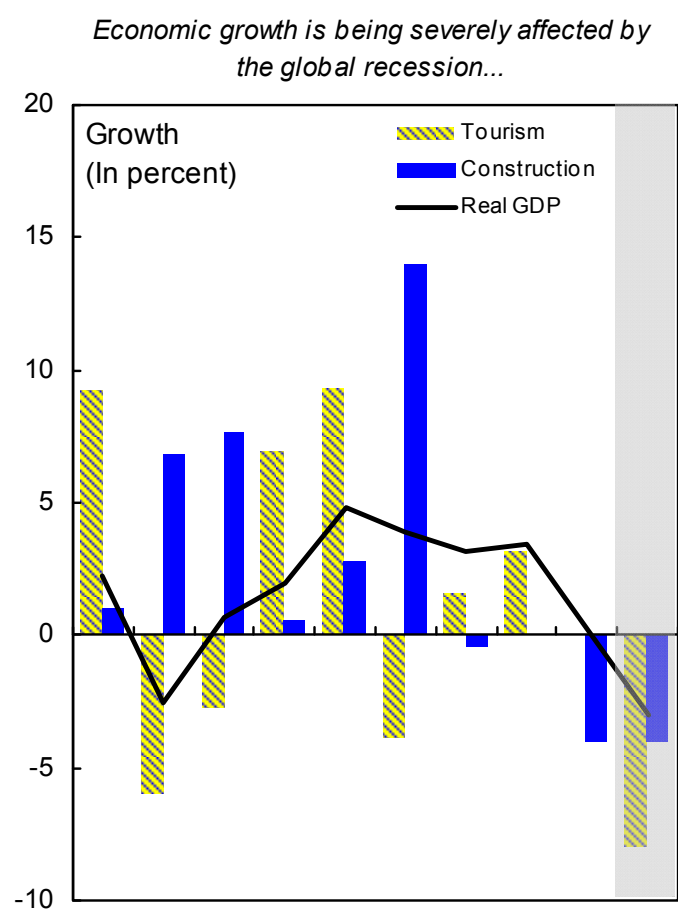

2000200120022003200420052006200720082009

The current account deficit is expected to narrow...

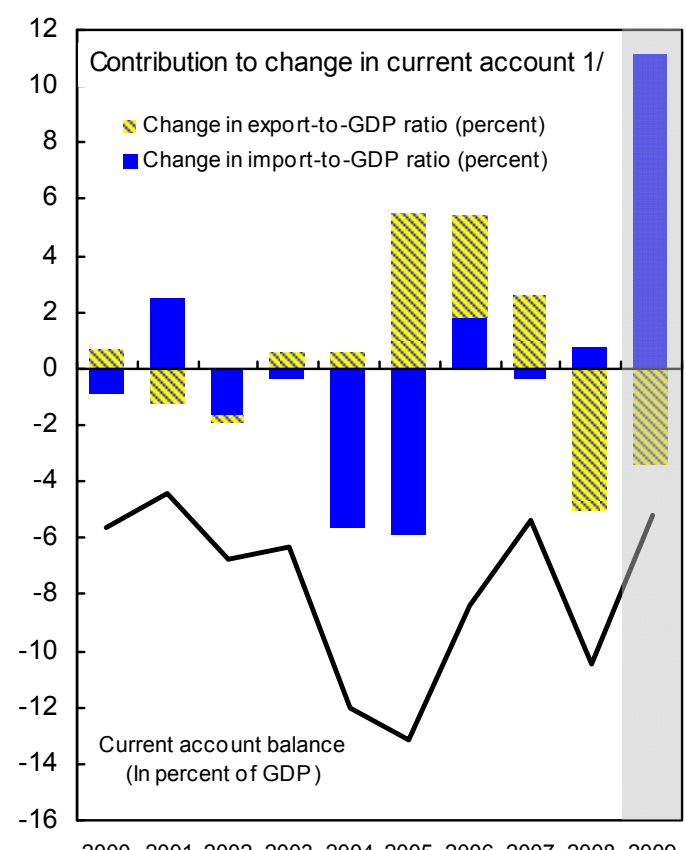

2000200120022003200420052006200720082009 ...while inflation is moderating, as domestic demand slackens.

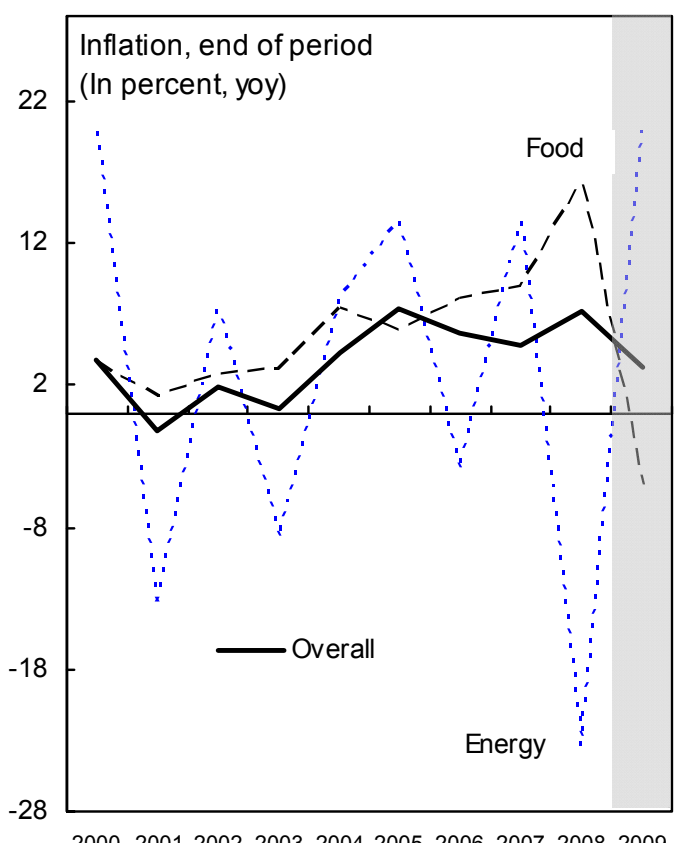

...but the effect on reserves will be offset by sharply lower private capital flows.

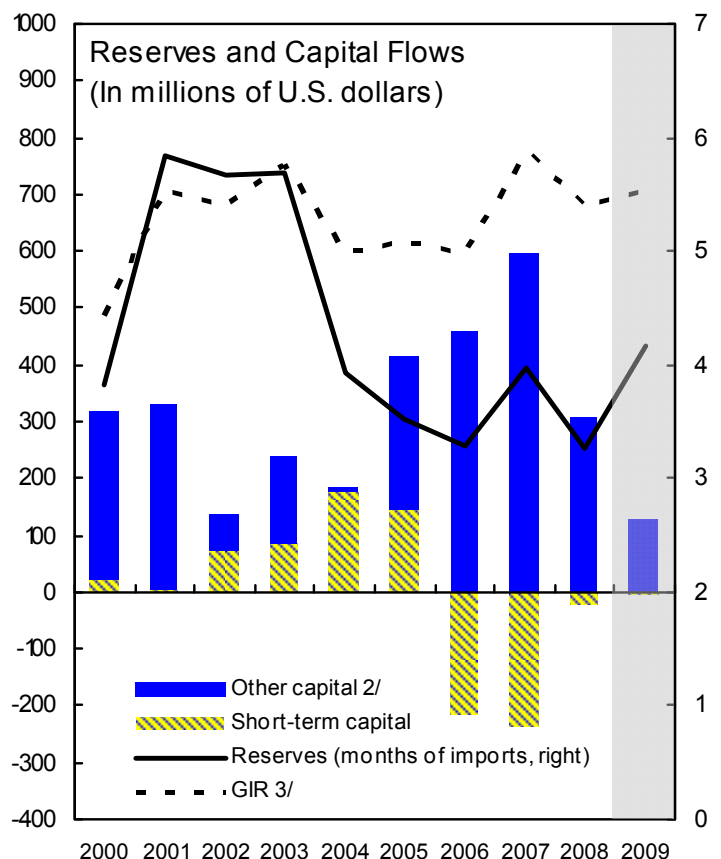

Sources: Central Bank of Barbados; and Fund staff projections.

$1 /$ An increase in the export (import) ratio is shown as a positive (negative) contribution, and vice versa. $2 /$ Includes errors and omissions.

3/ Includes the additional special and general SDR allocations in 2009. 
Figure 2. Barbados: Economic Performance in a Regional Context

Like other Caribbean countries, Barbados has been buffeted by the global crisis..

...and tourism arrivals, which experienced only slow growth over the last 5 years, has contracted sharply so far in 2009.
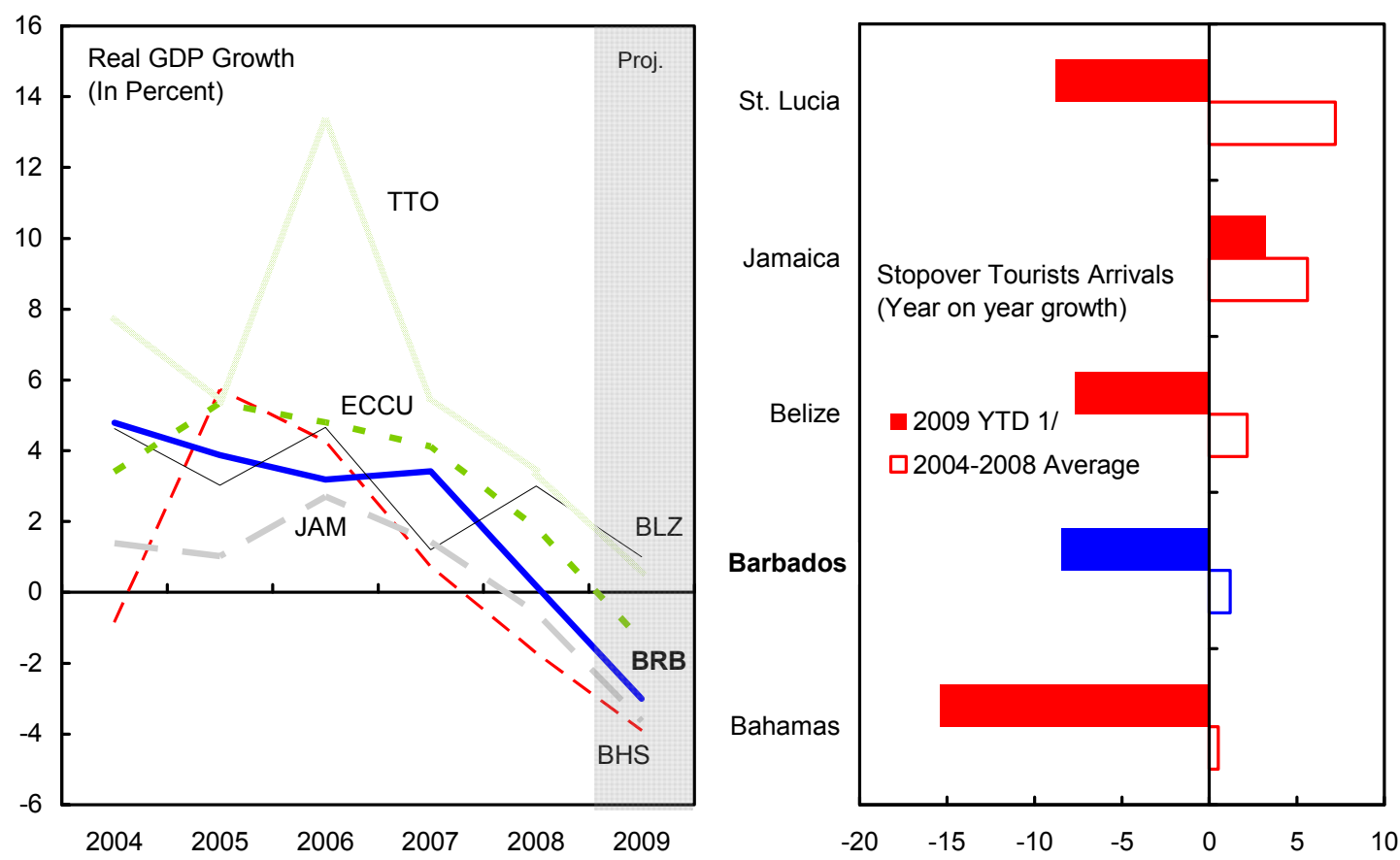

Barbados' fiscal position has deteriorated significantly, even compared to its neighbors...

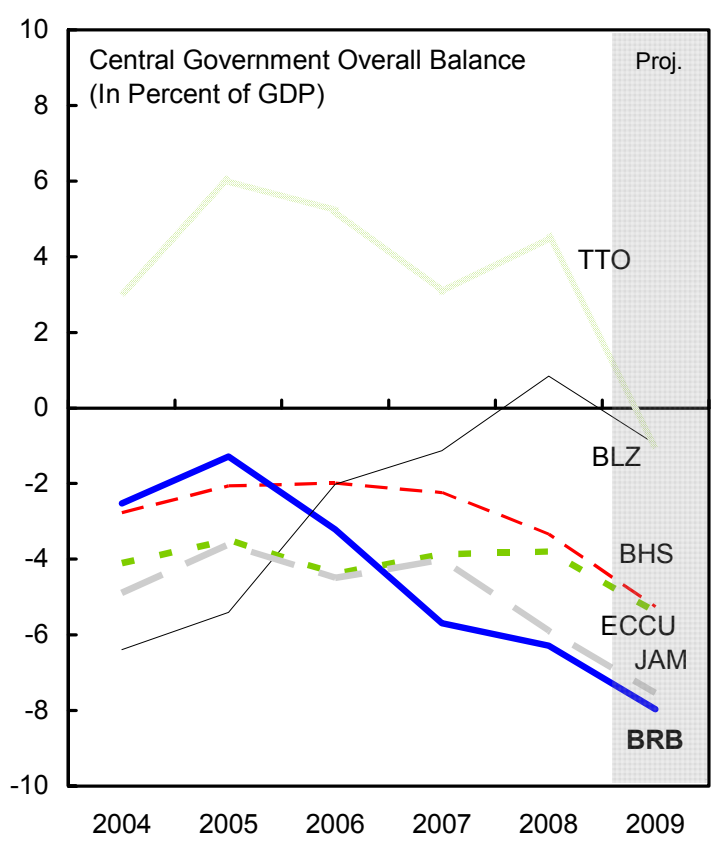

...further exacerbating an already difficult public debt position.

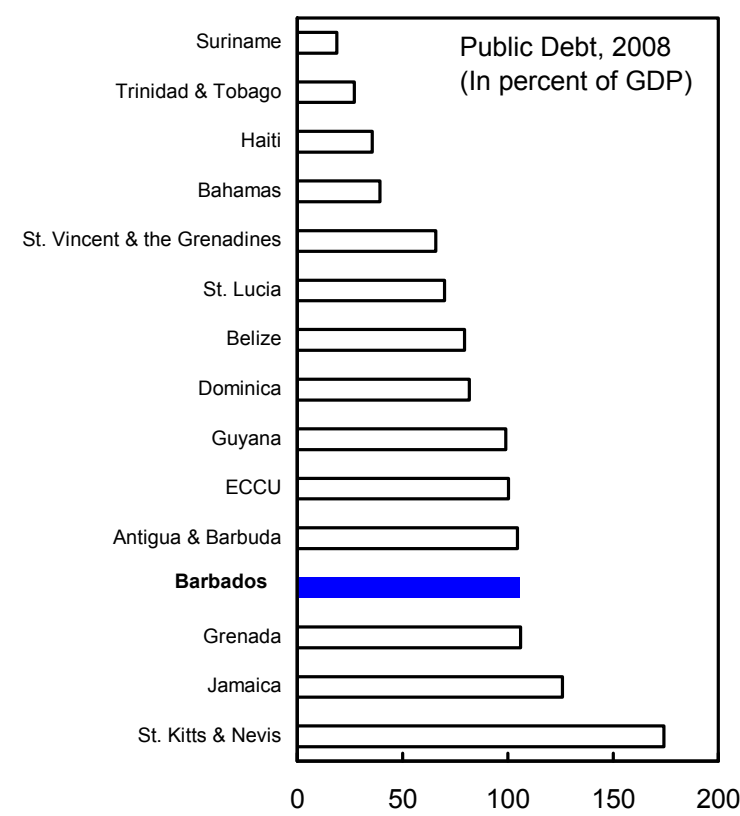

Sources: Central Bank of Barbados; Caribbean Tourism Organization; and Fund staff estimates.

1/ Data through: May 2009 for Jamaica and Barbados, April 2009 for St. Lucia and The Bahamas, and February 2009 for Belize. 
Figure 3. Barbados: Fiscal Sector Developments and Financing

The fiscal stance has weakened substantially in recent years...

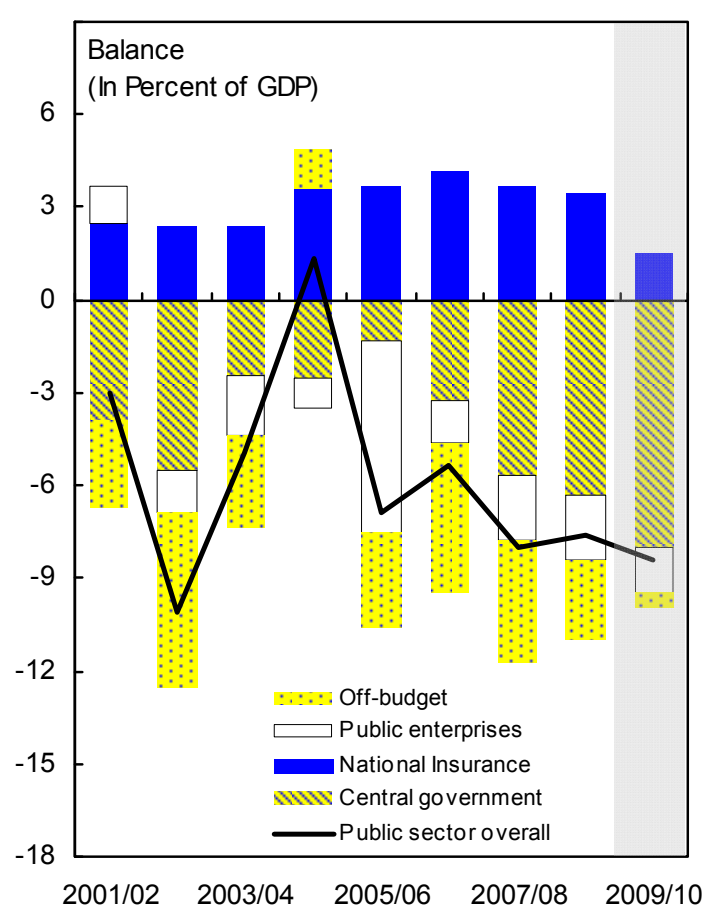

...leading to a rapid rise in the debt/GDP ratio.

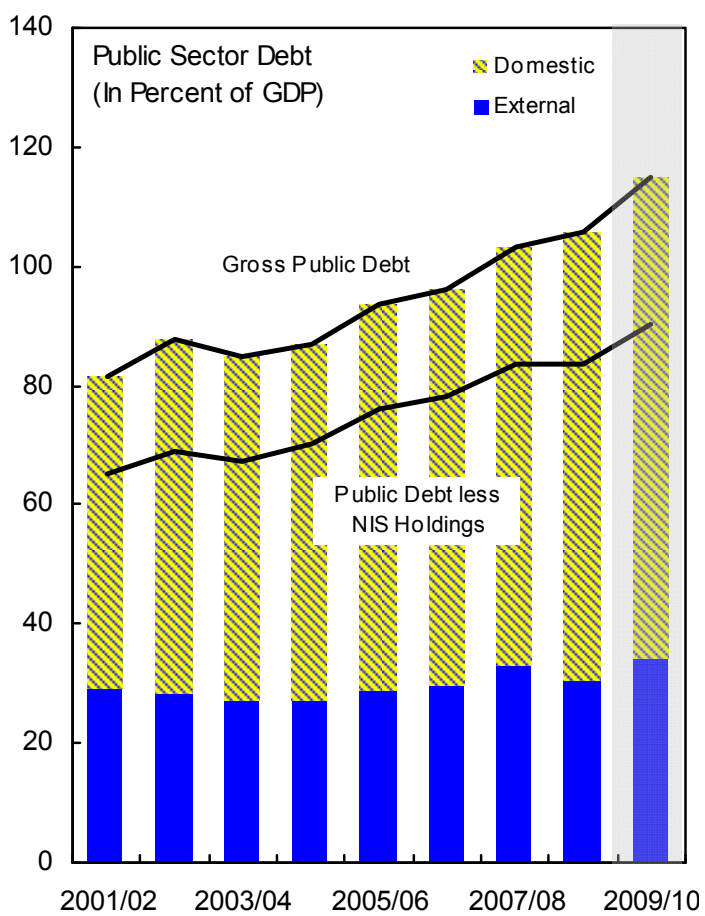

Barbados: Financing of the Nonfinancial Public Sector Operations, 2005/06-2010/11 (In percent of GDP)

\begin{tabular}{|c|c|c|c|c|c|c|}
\hline & 2005/06 & 2006/07 & $2007 / 08$ & $\begin{array}{r}\text { Est. } \\
2008 / 09\end{array}$ & $\begin{array}{r}\text { Proje } \\
2009 / 10\end{array}$ & $\frac{\text { ctions }}{2010 / 11}$ \\
\hline Overall public sector borrowing requirement & 6.9 & 5.3 & 8.0 & 7.6 & 8.4 & 7.1 \\
\hline Central government $1 /$ & 4.3 & 8.1 & 9.6 & 8.9 & 8.5 & 8.8 \\
\hline Central government & 4.3 & 8.6 & 9.8 & 8.9 & 8.5 & 8.8 \\
\hline $\begin{array}{l}\text { External (net) } \\
\text { Disbursements } \\
\text { Amortization } \\
\text { PPPs external (net) 2/ }\end{array}$ & $\begin{array}{l}3.6 \\
5.3 \\
1.8 \\
0.0\end{array}$ & $\begin{array}{l}2.8 \\
5.0 \\
2.2 \\
0.0\end{array}$ & $\begin{array}{l}4.9 \\
5.9 \\
1.6 \\
0.6\end{array}$ & $\begin{array}{r}-0.1 \\
1.1 \\
1.6 \\
0.4\end{array}$ & $\begin{array}{l}3.5 \\
4.4 \\
1.4 \\
0.4\end{array}$ & $\begin{array}{r}-3.2 \\
0.6 \\
3.8 \\
0.0\end{array}$ \\
\hline $\begin{array}{l}\text { Domestic (net) } \\
\text { Disbursements } \\
\text { Amortization } \\
\text { PPPs domestic (net) 2/ }\end{array}$ & $\begin{array}{r}0.8 \\
14.8 \\
14.0 \\
0.0\end{array}$ & $\begin{array}{r}5.8 \\
18.5 \\
12.7 \\
0.0\end{array}$ & $\begin{array}{r}4.8 \\
18.4 \\
13.6 \\
0.0\end{array}$ & $\begin{array}{r}9.0 \\
24.6 \\
16.0 \\
0.4\end{array}$ & $\begin{array}{r}5.1 \\
18.4 \\
13.5 \\
0.1\end{array}$ & $\begin{array}{r}12.0 \\
26.3 \\
14.3 \\
0.0\end{array}$ \\
\hline Government funds & 0.0 & -0.5 & -0.2 & -0.1 & -0.1 & 0.0 \\
\hline $\begin{array}{l}\text { Public enterprises } \\
\text { External (net) } \\
\text { Domestic (net) }\end{array}$ & $\begin{array}{r}6.3 \\
-0.4 \\
6.6\end{array}$ & $\begin{array}{r}1.4 \\
-0.3 \\
1.7\end{array}$ & $\begin{array}{l}2.1 \\
1.0 \\
1.2\end{array}$ & $\begin{array}{r}2.1 \\
-0.3 \\
2.4\end{array}$ & $\begin{array}{l}1.5 \\
0.0 \\
1.5\end{array}$ & $\begin{array}{l}1.5 \\
0.0 \\
1.5\end{array}$ \\
\hline $\begin{array}{l}\text { National Insurance Scheme } \\
\text { Banking system } \\
\text { Investments in government securities }\end{array}$ & $\begin{array}{r}-3.7 \\
1.2 \\
-1.7\end{array}$ & $\begin{array}{r}-4.1 \\
0.4 \\
-3.0\end{array}$ & $\begin{array}{r}-3.7 \\
0.4 \\
-2.7\end{array}$ & $\begin{array}{r}-3.4 \\
0.3 \\
-3.7\end{array}$ & $\begin{array}{r}-1.5 \\
0.7 \\
-2.1\end{array}$ & $\begin{array}{r}-3.3 \\
0.7 \\
-2.7\end{array}$ \\
\hline Others & -3.2 & -1.5 & -1.4 & 0.0 & -0.1 & -1.3 \\
\hline
\end{tabular}

Sources: Barbados authorities; and Fund staff estimates and projections.

$1 /$ Includes off-budget activities and general funds.

2/ Public-private partnerships. 
Table 1. Barbados: Selected Economic, Financial, and Social Indicators (Baseline)

I. Social and Demographic Indicators (most recent year)

\begin{tabular}{|c|c|c|c|c|c|c|}
\hline Population (people in millions) & 0.275 & & Adult literac & & & 99.4 \\
\hline Per capita GDP (in US\$) & 13,328 & & Population & ow pove & & 13.0 \\
\hline Life expectancy at birth in years & 75.4 & & Gini coeffic & & & 42.0 \\
\hline Rank in UNDP Development Index & 37 & & Unemployn & t rate & & 10.1 \\
\hline Main products, services and exports: tourism, financial se & es, rum, s & $\mathrm{r}$, and $\mathrm{cl}$ & emicals. & & & \\
\hline II. E & mic Indic & & & & & \\
\hline & & & & Prel. & Pro & \\
\hline & 2005 & 2006 & 2007 & 2008 & 2009 & 2010 \\
\hline & & (An & nual percen & e change & & \\
\hline National accounts and prices & & & & & & \\
\hline Real GDP & 3.9 & 3.2 & 3.4 & 0.2 & -3.0 & 0.0 \\
\hline Deflator & 2.7 & 2.9 & 3.3 & 7.4 & 1.0 & 1.0 \\
\hline Nominal GDP & 6.7 & 6.2 & 6.8 & 7.6 & -2.0 & 1.0 \\
\hline CPI inflation (average) & 6.1 & 7.3 & 4.0 & 8.1 & 3.5 & 5.2 \\
\hline $\mathrm{CPI}$ inflation (end of period) & 7.3 & 5.7 & 4.8 & 7.2 & 3.2 & 7.2 \\
\hline Domestic demand (contribution to growth) & -3.2 & -2.8 & 0.9 & -0.1 & -6.6 & 2.7 \\
\hline Foreign demand (contribution to growth) & 7.1 & 6.0 & 2.5 & 0.3 & 3.6 & -2.7 \\
\hline External sector & & & & & & \\
\hline Exports of goods and services & 18.4 & 13.1 & 11.5 & -1.1 & -7.8 & -1.5 \\
\hline Imports of goods and services & 16.4 & 3.4 & 7.4 & 6.4 & -18.1 & 5.7 \\
\hline Real effective exchange rate (average) & 1.6 & 3.4 & -2.4 & 3.9 & $\ldots$ & $\ldots$ \\
\hline Terms of trade & -5.9 & -3.8 & -0.5 & -3.2 & 7.5 & -3.2 \\
\hline Money and credit (end of period) & & & & & & \\
\hline Net domestic assets & 14.1 & 14.2 & 9.4 & 13.7 & 3.0 & 9.5 \\
\hline Of which: private sector credit & 21.7 & 13.2 & 6.4 & 11.1 & -0.7 & 1.9 \\
\hline Broad money & 6.9 & 11.3 & 13.2 & 2.8 & 4.5 & 5.4 \\
\hline Velocity (GDP relative to broad money) & 1.2 & 1.1 & 1.1 & 1.1 & 1.1 & 1.0 \\
\hline & & ercent o & GDP, unles & therwise & licated) & \\
\hline Public finances (fiscal year) & & & & & & \\
\hline Nonfinancial public sector overall balance & -6.9 & -5.3 & -8.0 & -7.6 & -8.4 & -7.1 \\
\hline Central Government & & & & & & \\
\hline Revenue and grants & 35.1 & 34.2 & 36.5 & 34.9 & 32.9 & 33.7 \\
\hline Expenditure & 36.4 & 37.5 & 42.3 & 41.3 & 41.1 & 42.6 \\
\hline Interests & 4.8 & 5.0 & 5.6 & 5.4 & 5.1 & 6.4 \\
\hline Balance & -1.3 & -3.2 & -5.7 & -6.3 & -8.0 & -8.9 \\
\hline NIS & 3.7 & 4.1 & 3.7 & 3.4 & 1.5 & 3.3 \\
\hline Public enterprises & -6.3 & -1.4 & -2.1 & -2.1 & -1.5 & -1.5 \\
\hline Off-budget activities & -3.0 & -4.9 & -3.9 & -2.6 & -0.5 & 0.0 \\
\hline Primary balance & -3.2 & -1.5 & -3.4 & -3.4 & -4.6 & -2.4 \\
\hline Debt & & & & & & \\
\hline Public sector (fiscal year) & 93.7 & 96.2 & 103.3 & 105.9 & 115.1 & 123.0 \\
\hline External & 28.9 & 29.6 & 32.9 & 30.6 & 34.4 & 30.5 \\
\hline Domestic & 64.9 & 66.6 & 70.3 & 75.3 & 80.6 & 92.5 \\
\hline Savings and investment & & & & & & \\
\hline Gross domestic investment & 24.8 & 26.6 & 26.8 & 23.7 & 7.0 & 12.0 \\
\hline Public & 6.9 & 7.6 & 7.5 & 9.2 & 3.5 & 3.0 \\
\hline Private & 18.0 & 19.0 & 19.4 & 14.5 & 3.5 & 9.0 \\
\hline National savings & 11.7 & 18.3 & 21.5 & 13.2 & 1.8 & 6.1 \\
\hline Public & 0.0 & 2.3 & -0.8 & -2.4 & -4.9 & -4.0 \\
\hline Private & 11.7 & 16.0 & 22.3 & 15.6 & 6.8 & 10.1 \\
\hline External savings & 13.1 & 8.4 & 5.4 & 10.5 & 5.2 & 5.9 \\
\hline Balance of payments & & & & & & \\
\hline Current account & -13.1 & -8.4 & -5.4 & -10.5 & -5.2 & -5.9 \\
\hline Capital and financial account & 13.9 & 7.7 & 10.6 & 7.9 & 3.5 & 3.4 \\
\hline Official capital & 4.2 & 1.5 & -2.1 & -0.6 & 2.9 & -1.4 \\
\hline Private capital $1 /$ & 9.8 & 6.2 & 12.7 & 8.4 & 0.6 & 4.8 \\
\hline Of which: long-term flows & 1.0 & 14.0 & 21.4 & 5.1 & 1.5 & 4.2 \\
\hline Overall balance & 0.8 & -0.7 & 5.2 & -2.6 & -1.6 & -2.5 \\
\hline Memorandum items: & & & & & & \\
\hline Exchange rate (in Barbados dollars per U.S. dollar) & 2.0 & 2.0 & 2.0 & 2.0 & 2.0 & 2.0 \\
\hline Gross international reserves (in millions of US dollars)2/ & 618.2 & 597.0 & 774.0 & 678.1 & 707.4 & 616.3 \\
\hline In months of imports & 3.5 & 3.3 & 4.0 & 3.3 & 4.2 & 3.4 \\
\hline Nominal GDP (in millions of Barbados dollars) & 6,010 & 6,382 & 6,819 & 7,338 & 7,191 & 7,263 \\
\hline
\end{tabular}

Sources: Central Bank of Barbados; and Fund staff estimates and projections.

$1 /$ Includes short-term and long-term flows, and errors and omissions.

$2 /$ Includes the additional special and general SDR allocations. 
Table 2. Barbados: Nonfinancial Public Sector Operations 1/ (Baseline)

(In percent of GDP, unless otherwise indicated)

\begin{tabular}{|c|c|c|c|c|c|c|}
\hline \multirow[b]{2}{*}{ Public sector } & \multirow[t]{2}{*}{$2005 / 06$} & \multirow[t]{2}{*}{$2006 / 07$} & \multirow[t]{2}{*}{$\begin{array}{r}\text { Rev. } \\
2007 / 08\end{array}$} & \multirow[t]{2}{*}{$\begin{array}{r}\text { Est. } \\
2008 / 09\end{array}$} & \multicolumn{2}{|c|}{$\begin{array}{c}\text { Proj. } \\
2009 / 10 \quad 2010 / 11\end{array}$} \\
\hline & & & & & & \\
\hline Current revenue & 40.0 & 41.1 & 42.7 & 40.3 & 38.2 & 39.3 \\
\hline Current expenditure & 37.6 & 37.6 & 42.6 & 43.5 & 44.9 & 45.2 \\
\hline Interest to the private sector & 4.8 & 5.0 & 5.7 & 5.3 & 4.8 & 6.0 \\
\hline External & 1.8 & 1.9 & 2.3 & 2.3 & 2.1 & 2.5 \\
\hline Domestic & 3.0 & 3.1 & 3.4 & 3.0 & 2.7 & 3.5 \\
\hline Capital revenue & 2.6 & 2.9 & 2.8 & 2.9 & 3.0 & 3.5 \\
\hline Of which: interest from the private sector & 1.1 & 1.2 & 1.2 & 1.0 & 0.9 & 1.3 \\
\hline Capital expenditure & 8.8 & 6.9 & 7.0 & 4.7 & 4.3 & 4.6 \\
\hline Balance & -3.8 & -0.5 & -4.1 & -5.0 & -8.0 & -7.1 \\
\hline Off-budget activity balance & -3.0 & -4.9 & -3.9 & -2.6 & -0.5 & 0.0 \\
\hline Off-budget investment & -3.1 & -5.4 & -3.5 & -1.9 & 0.0 & 0.0 \\
\hline PPPs & 0.0 & 0.0 & -0.6 & -0.8 & -0.6 & 0.0 \\
\hline Funds & 0.0 & 0.5 & 0.2 & 0.1 & 0.1 & 0.0 \\
\hline Overall balance & -6.9 & -5.3 & -8.0 & -7.6 & -8.4 & -7.1 \\
\hline Of which: primary balance & -3.2 & -1.5 & -3.4 & -3.4 & -4.6 & -2.4 \\
\hline \multicolumn{7}{|l|}{ National Insurance Scheme (NIS) } \\
\hline Current revenue & 6.9 & 7.1 & 7.3 & 7.2 & 6.0 & 6.3 \\
\hline Current expenditure & 5.3 & 5.3 & 5.8 & 5.7 & 6.5 & 6.0 \\
\hline Capital revenue & 2.2 & 2.3 & 2.4 & 2.2 & 2.2 & 2.8 \\
\hline Of which: interest from central government & 1.1 & 1.1 & 1.2 & 1.1 & 1.2 & 1.5 \\
\hline Capital expenditure & 0.0 & 0.0 & 0.1 & 0.2 & 0.2 & -0.2 \\
\hline NIS Balance & 3.7 & 4.1 & 3.7 & 3.4 & 1.5 & 3.3 \\
\hline \multicolumn{7}{|l|}{ Central government } \\
\hline Current revenue & 35.1 & 34.2 & 36.5 & 34.9 & 32.9 & 33.7 \\
\hline Current expenditure & 32.3 & 32.3 & 36.8 & 37.8 & 38.4 & 39.2 \\
\hline Of which: interest payments & 4.8 & 5.0 & 5.6 & 5.4 & 5.1 & 6.4 \\
\hline External & 1.5 & 1.7 & 2.0 & 2.0 & 1.8 & 2.3 \\
\hline Domestic & 3.3 & 3.4 & 3.6 & 3.4 & 3.3 & 4.1 \\
\hline Capital revenue and grants & 0.0 & 0.0 & 0.1 & 0.1 & 0.2 & 0.1 \\
\hline Capital expenditure and net lending & 4.1 & 5.1 & 5.5 & 3.5 & 2.7 & 3.5 \\
\hline Balance & -1.3 & -3.2 & -5.7 & -6.3 & -8.0 & -8.9 \\
\hline Public enterprises balance & -6.3 & -1.4 & -2.1 & -2.1 & -1.5 & -1.5 \\
\hline Total financing & 6.9 & 5.3 & 8.0 & 7.6 & 8.4 & 7.1 \\
\hline Foreign financing & 3.2 & 2.5 & 5.9 & -0.3 & 3.5 & -3.2 \\
\hline Central Government & 3.6 & 2.8 & 4.9 & -0.1 & 3.5 & -3.2 \\
\hline Disbursements & 5.3 & 5.0 & 5.9 & 1.1 & 4.4 & 0.6 \\
\hline Amortization & -1.8 & -2.2 & -1.6 & -1.6 & -1.4 & -3.8 \\
\hline Privatization receipts & 0.0 & 0.0 & 0.0 & 0.0 & 0.0 & 0.0 \\
\hline Public enterprises & -0.4 & -0.3 & 1.0 & -0.3 & 0.0 & 0.0 \\
\hline Domestic financing & 3.7 & 2.8 & 2.1 & 7.9 & 5.0 & 10.2 \\
\hline Central government & 0.8 & 5.8 & 4.9 & 9.0 & 5.1 & 12.0 \\
\hline Public enterprises & 6.6 & 1.7 & 1.2 & 2.4 & 1.5 & 1.5 \\
\hline National Insurance Scheme & -3.7 & -4.1 & -3.7 & -3.4 & -1.5 & -3.3 \\
\hline Funds & 0.0 & -0.5 & -0.2 & -0.1 & -0.1 & 0.0 \\
\hline \multicolumn{7}{|l|}{ Memorandum items: } \\
\hline Public sector revenue and grants, excluding NIS & 48.6 & 50.6 & 52.6 & 52.3 & 51.5 & 52.1 \\
\hline Public sector expenditure, excluding NIS & 59.1 & 60.0 & 64.3 & 63.3 & 61.4 & 62.5 \\
\hline Of which: interest payments & 5.9 & 6.1 & 6.9 & 6.4 & 6.1 & 7.5 \\
\hline Public sector balance, excluding NIS & -10.6 & -9.5 & -11.7 & -11.0 & -10.0 & -10.4 \\
\hline Nominal fiscal year GDP (in millions of Barbados dollars) & 6,103 & 6,491 & 6,948 & 7,301 & 7,209 & 7,365 \\
\hline
\end{tabular}

Sources: Ministry of Finance; and Fund staff estimates.

1/ Fiscal year (April-March). Ratios expressed relative to fiscal-year GDP. 
Table 3. Barbados: Public Sector Debt (Baseline) 1/

\begin{tabular}{|c|c|c|c|c|c|}
\hline & $2005 / 06$ & $2006 / 07$ & $\begin{array}{r}\text { Rev. } \\
2007 / 08\end{array}$ & $\begin{array}{r}\text { Est. } \\
2008 / 09\end{array}$ & $\begin{array}{r}\text { Proj. } \\
2009 / 10\end{array}$ \\
\hline & \multicolumn{5}{|c|}{ (In millions of Barbados dollars) } \\
\hline Public sector & 5,721 & 6,247 & 7,175 & 7,734 & 8,296 \\
\hline External & 1,762 & 1,924 & 2,288 & 2,233 & 2,483 \\
\hline Domestic & 3,959 & 4,323 & 4,887 & 5,501 & 5,814 \\
\hline Central government & 4,765 & 5,200 & 5,982 & 6,650 & 7,103 \\
\hline External 2/ & 1,535 & 1,717 & 2,015 & 1,980 & 2,229 \\
\hline Domestic & 3,230 & 3,484 & 3,967 & 4,670 & 4,874 \\
\hline Short term & 606 & 635 & 830 & 943 & 699 \\
\hline Long term & 2,624 & 2,849 & 3,122 & 3,727 & 4,175 \\
\hline Government guaranteed & 956 & 1,047 & 1,193 & 1,084 & 1,193 \\
\hline External 2/ & 227 & 207 & 273 & 253 & 253 \\
\hline \multirow[t]{2}{*}{ Domestic } & 729 & 840 & 920 & 831 & 940 \\
\hline & \multicolumn{5}{|c|}{ (In percent of GDP) } \\
\hline Public sector & 93.7 & 96.2 & 103.3 & 105.9 & 115.1 \\
\hline External & 28.9 & 29.6 & 32.9 & 30.6 & 34.4 \\
\hline Domestic & 64.9 & 66.6 & 70.3 & 75.3 & 80.6 \\
\hline Central government & 78.1 & 80.1 & 86.1 & 91.1 & 98.5 \\
\hline External 2/ & 25.1 & 26.4 & 29.0 & 27.1 & 30.9 \\
\hline Domestic & 52.9 & 53.7 & 57.1 & 64.0 & 67.6 \\
\hline Short term & 9.9 & 9.8 & 9.7 & 9.7 & 9.7 \\
\hline Long term & 43.0 & 43.9 & 47.4 & 54.3 & 57.9 \\
\hline Government guaranteed & 15.7 & 16.1 & 17.2 & 14.8 & 16.5 \\
\hline External 2/ & 3.7 & 3.2 & 3.9 & 3.5 & 3.5 \\
\hline Domestic & 11.9 & 12.9 & 13.2 & 11.4 & 13.0 \\
\hline \multicolumn{6}{|l|}{ Memorandum items: } \\
\hline NIS financial assets & 35.6 & 37.6 & 39.4 & 40.9 & 43.0 \\
\hline NIS holdings of central government debt & 17.7 & 18.0 & 19.6 & 22.4 & 24.7 \\
\hline Public sector debt less NIS assets & 58.2 & 58.6 & 63.8 & 65.0 & 72.1 \\
\hline Public sector debt less NIS holdings & 76.0 & 78.2 & 83.7 & 83.5 & 90.3 \\
\hline Assets held in earmarked sinking funds & 7.2 & 7.6 & 7.9 & 8.8 & 9.6 \\
\hline Public debt, excl. sinking funds & 86.5 & 88.6 & 95.3 & 97.1 & 105.5 \\
\hline
\end{tabular}

Sources: Ministry of Finance; Central Bank of Barbados; and Fund staff estimates and projections.

1/ Fiscal year (April-March). Ratios expressed relative to fiscal-year GDP.

2/ External debt is all medium- and long-term debt. 
Table 4. Barbados: Balance of Payments (Baseline) (In millions of U.S. dollars)

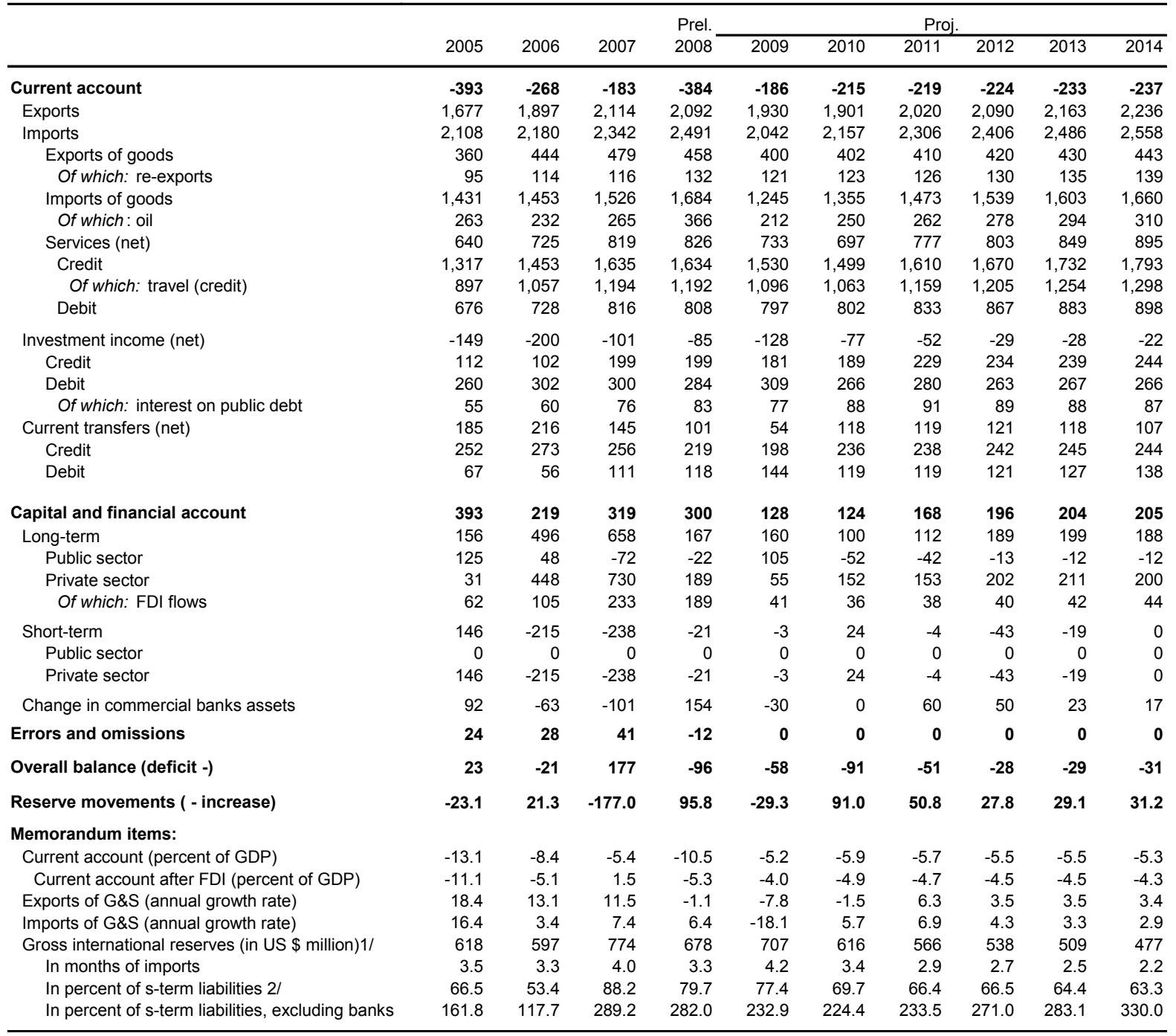

Sources: Central Bank of Barbados; and Fund staff estimates and projections.

$1 /$ Includes the additional special and general SDR allocations.

2/ Includes maturing public sector short-term external debt, banks' short-term foreign liabilities, and an estimate of nonbank short-term foreign liabilities based on capital account inflows since 2003 
Table 5. Barbados: Selected Vulnerability Indicators (Baseline)

(In percent of GDP, unless otherwise indicated)

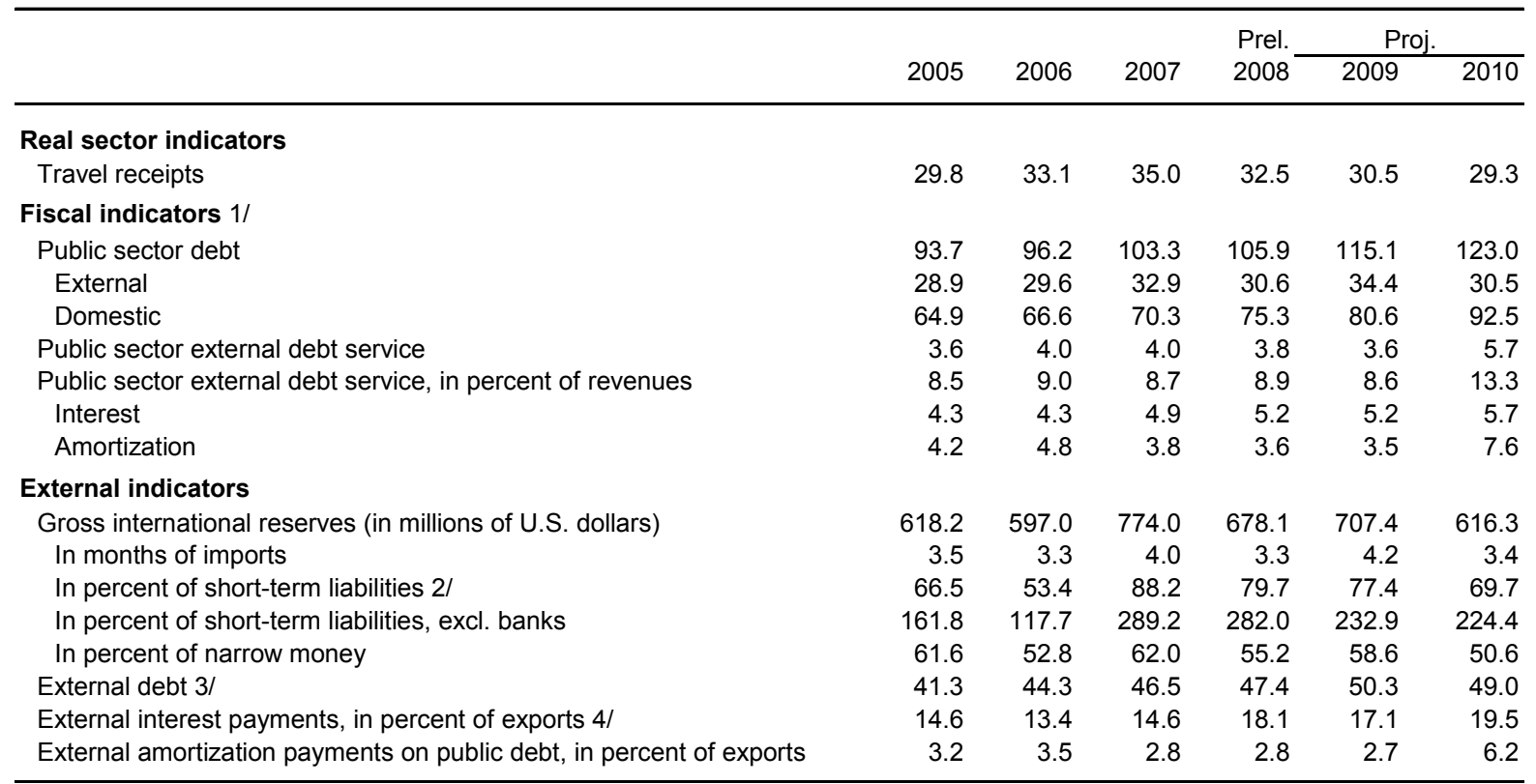

Sources: Central Bank of Barbados; and Fund staff estimates and projections.

$1 /$ On a fiscal-year basis, including central government, public enterprises, and National Insurance Scheme.

2/ Includes maturing public sector short-term external debt, banks' short-term foreign liabilities, and an estimate of nonbank short-term foreign liabilities based on capital account inflows since 2003.

$3 /$ Includes public sector and nonbank private debt.

4/ Includes interest payments on public and private external debt. 


\section{APPENDIX I. ILLUSTRATIVE SCENARIOS AND DEBT SUSTAINABILITY ANALYSES (DSAS)}

The staff conducted debt sustainability analyses, based on two scenarios for the medium-term outlook: (i) a baseline "passive" scenario that assumed current policies would be broadly maintained for the foreseeable future; and (ii) an adjustment "active" scenario that assumed that a number of corrective measures - mainly in the fiscal sector — would be implemented beginning in FY 2009/10 (April to March).

\section{A. Key Assumptions and Scenarios}

A number of assumptions are common to both the baseline and adjustment scenarios. These include the same price developments, a stable exchange rate peg, and a recovery in the global demand for Barbados's goods and services, starting in 2010. Both scenarios also assume that no new large private-public-partnerships projects will be undertaken, and there will be no costs to the budget arising from the resolution of the problems of CLICOBarbados. On the external side, both scenarios assume the special and general SDR allocations totaling US $\$ 88$ million will be approved and will come into effect in the second half of 2009. Likewise, it is assumed that some private capital inflows will resume in the second half of 2009 to finance a number of stalled tourism projects.

\section{Baseline scenario}

The baseline scenario is premised on an unchanged fiscal policy stance. The nonfinancial public sector (NFPS) deficit would rise from 71/2 percent of GDP in FY 2008/09 to $81 / 2$ percent of GDP in FY 2009/10. While the overall balance would improve as the country emerges from recession, the NFPS deficit would remain at around 5 percent over the medium term. As a result, gross public debt would rise along an upward trajectory from 106 percent of GDP at end-FY 2008/09 to more than 130 percent of GDP by the end of FY 2014/15. At the same time, the current account deficit would remain at about 5-6 percent of GDP. Capital will continue to flow into the country at a weak pace, and it will be insufficient to cover the current account deficit. Accordingly, reserves would decline from currently about 3.3 months of imports to 2.2 months of imports at end-FY 2014.

\section{Adjustment scenario}

In the adjustment scenario, it is assumed that the authorities will tighten fiscal policies in the context of a medium-term fiscal consolidation plan. This will start with a modest effort of 1 percent of GDP in FY 2009/10. While some small improvements are projected in revenue collections, the bulk of the fiscal efforts would take place in moderating and prioritizing expenditures. The improved fiscal outlook would result in the NFPS moving 
from a deficit of 71/2 of GDP on FY 2008/09 to a surplus of $31 \frac{1}{2}$ percent of GDP in FY 2014/15, and gross debt, after peaking in FY 2010/11 at close to 119 percent of GDP, would steadily decline along a downward path to 103 percent of GDP by the end of the projection period. Real GDP would contract moderately in 2009 , reflecting the demand withdrawal from expenditure savings in FY 2009/10, but subsequently rebound quicker and remain higher, as investor confidence in the government's adjustment policies recovers and private capital inflows resume at a healthier pace, with higher FDI, particularly in

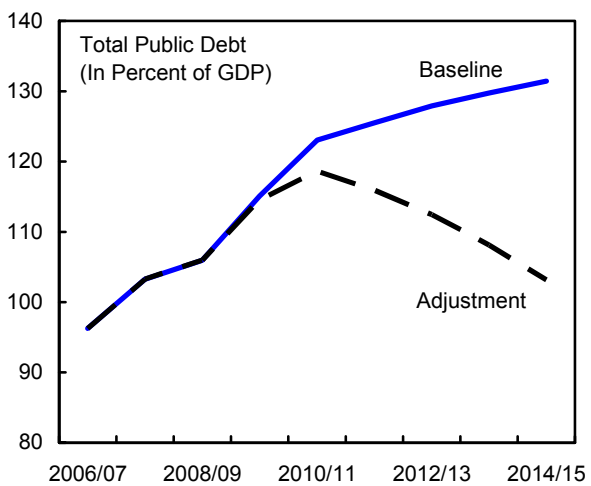
the tourism and offshore financial sectors. The higher growth in the outer years would also contribute to improved debt dynamics, as would lower spreads on government debt.

\section{The fiscal consolidation effort will also improve the balance of payments outlook. As investor confidence} strengthens, current and capital inflows in general, and FDI in particular, will rebound. As a result, the current account deficit will narrow, compared to the baseline scenario. International reserves, rather than trending downward, will broadly stabilize during 2010-11, and then rise steadily to reach about US\$970 million, or 4.5 months of imports, by the end of the projection period.

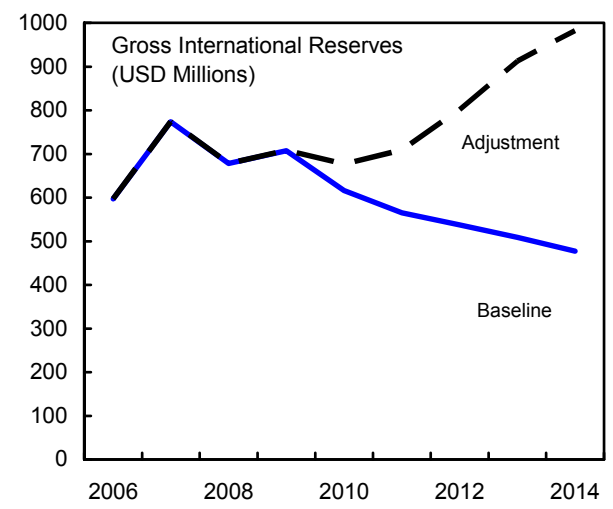

Illustrative Scenarios 1/ (In percent of GDP)

\begin{tabular}{|c|c|c|c|c|c|c|c|c|}
\hline & \multirow{2}{*}{$\begin{array}{r}\text { Rev. } \\
2007 / 08 \\
\end{array}$} & \multirow{2}{*}{$\begin{array}{r}\text { Est. } \\
2008 / 09 \\
\end{array}$} & \multicolumn{6}{|c|}{ Proj. } \\
\hline & & & $2009 / 10$ & $2010 / 11$ & $2011 / 12$ & $2012 / 13$ & $2013 / 14$ & $2014 / 15$ \\
\hline \multicolumn{9}{|l|}{ Baseline Scenario } \\
\hline \multicolumn{9}{|l|}{ Fiscal } \\
\hline Public sector balance & -8.0 & -7.6 & -8.4 & -7.1 & -4.9 & -4.6 & -3.8 & -3.4 \\
\hline Primary balance & -3.4 & -3.4 & -4.6 & -2.4 & 0.2 & 0.7 & 1.6 & 1.8 \\
\hline Revenues & 45.5 & 43.2 & 41.2 & 42.8 & 45.0 & 45.6 & 46.5 & 46.8 \\
\hline Primary expenditure & 49.0 & 46.6 & 45.8 & 45.1 & 44.7 & 44.9 & 45.0 & 45.0 \\
\hline Public Debt & 103.3 & 105.9 & 115.1 & 123.0 & 125.5 & 127.9 & 129.8 & 131.4 \\
\hline \multicolumn{9}{|l|}{ External } \\
\hline Current account balance & -5.4 & -10.5 & -5.2 & -5.9 & -5.7 & -5.5 & -5.5 & -5.3 \\
\hline FDI Inflows & 6.8 & 5.1 & 1.1 & 1.0 & 1.0 & 1.0 & 1.0 & 1.0 \\
\hline GIR (in U.S. dollar millions) & 774.0 & 678.1 & 707.4 & 616.3 & 565.5 & 537.7 & 508.6 & 477.5 \\
\hline GIR (in months of imports) & 4.0 & 3.3 & 4.2 & 3.4 & 2.9 & 2.7 & 2.5 & 2.2 \\
\hline Real GDP (annual percent change) & 3.4 & 0.2 & -3.0 & 0.0 & 3.0 & 2.5 & 2.5 & 2.5 \\
\hline \multicolumn{9}{|l|}{$\begin{array}{l}\text { Adjustment Scenario } \\
\text { Fiscal }\end{array}$} \\
\hline Public sector balance & -8.0 & -7.6 & -7.5 & -3.9 & -1.1 & 0.7 & 2.3 & 3.6 \\
\hline Primary balance & -3.4 & -3.4 & -3.6 & 0.5 & 3.6 & 5.0 & 6.3 & 7.2 \\
\hline Revenues & 45.5 & 43.2 & 41.4 & 43.2 & 44.8 & 45.6 & 46.3 & 46.8 \\
\hline Primary expenditure & 49.0 & 46.6 & 45.0 & 42.7 & 41.2 & 40.6 & 40.0 & 39.5 \\
\hline Public Debt & 103.3 & 105.9 & 114.6 & 118.6 & 115.9 & 112.4 & 108.1 & 103.2 \\
\hline \multicolumn{9}{|l|}{ External } \\
\hline Current account balance & -5.4 & -10.5 & -5.2 & -5.3 & -5.5 & -5.0 & -4.7 & -4.3 \\
\hline FDI Inflows & 6.8 & 5.1 & 1.1 & 2.0 & 3.0 & 3.4 & 3.4 & 2.2 \\
\hline GIR (in U.S. dollar millions) & 774.0 & 678.1 & 708.3 & 677.1 & 708.6 & 801.2 & 912.9 & 981.9 \\
\hline GIR (in months of imports) & 4.0 & 3.3 & 4.2 & 3.8 & 3.6 & 3.9 & 4.3 & 4.5 \\
\hline Real GDP (annual percent change) & 3.4 & 0.2 & -3.5 & 0.5 & 4.5 & 3.5 & 3.2 & 3.0 \\
\hline
\end{tabular}

Sources: Central Bank of Barbados; and Fund staff projections.

$1 /$ GDP and external data are in calendar year. 


\section{B. Assessment of DSAs}

\section{Baseline scenario}

Bounds tests reveal that the path of debt could be affected considerably in response to standard shocks. Public debt under the baseline scenario, as discussed above, will increase continuously over the projection period to 131 percent of GDP. Debt ratios are particularly sensitive to a growth and fiscal shocks. Should economic growth decline on a permanent basis by $1 / 2$ standard deviation from its historic trend, public debt at the end of the projection period would rise to 146 percent of GDP. In the same way, if the primary balance were to continue in line with its historic trend, public debt would reach 150 percent of GDP at the end of the projection period.

External debt is less sensitive to standard shocks. This is mainly on account of the relatively low share of external debt relative to total debt (less than one-third). Total private and public external debt is estimated at about 47 percent of GDP at end-2008, and after peaking in 2009, is likely to fall under the baseline scenario to about 40 percent of GDP by the end of the projection period. However, as can be expected, external debt is most sensitive to a real depreciation shock. Accordingly, an illustrative depreciation of 30 percent would raise the external debt to 56 percent of GDP by the end of the projection period. Another perspective is to estimate the potential shock arising from an increase in the price of oil by 30 percent above current WEO projections, starting in 2010. This would widen the current account deficit by 2 percent of GDP, and could lead, everything else left unchanged, to a depletion of reserves by 2014.

\section{Adjustment scenario}

Under the active scenario, rather than climbing steadily, public debt will peak in FY 2010/11 and then trend downward. The public debt outlook improves considerably, thanks to positive and sustained fiscal balances, higher overall growth, and lower interest rates and payments. Bound tests also reveal a much-reduced vulnerability to the standard stresses, suggesting that public debt would continue to fall even after these shocks hit the economy. A similar improvement is also evident in stress tests to the external debt outlook. 
Appendix Table 1. Barbados: Public Sector Debt Sustainability Framework, 2004-2014 (Baseline Scenario)

(In percent of GDP, unless otherwise indicated)

\begin{tabular}{|c|c|c|c|c|c|c|c|c|c|c|c|c|}
\hline & \multicolumn{5}{|c|}{ Actual } & \multicolumn{6}{|c|}{ Projections } & \multirow{3}{*}{$\begin{array}{c}\text { Debt-stabilizing } \\
\text { primary } \\
\text { balance 9/ }\end{array}$} \\
\hline & 2004 & 2005 & 2006 & 2007 & 2008 & 2009 & 2010 & 2011 & 2012 & 2013 & 2014 & \\
\hline \multirow{3}{*}{$\begin{array}{l}1 \text { Baseline: Public sector debt } 1 / \\
\text { Of which: foreign-currency denominated }\end{array}$} & & & & & & & & & & & & \\
\hline & 87.1 & 93.7 & 96.2 & 103.3 & 105.9 & 115.1 & 123.0 & 125.5 & 127.9 & 129.8 & 131.4 & 2.6 \\
\hline & 27.3 & 28.9 & 29.6 & 32.9 & 30.6 & 34.4 & 30.5 & 28.5 & 26.9 & 25.3 & 23.8 & \\
\hline 2 Change in public sector debt & 2.2 & 6.6 & 2.5 & 7.0 & 2.7 & 9.2 & 7.9 & 2.5 & 2.4 & 1.9 & 1.6 & \\
\hline 3 Identified debt-creating flows $(4+7+12)$ & -1.9 & 5.2 & 3.9 & 5.3 & 6.0 & 11.3 & 7.9 & 2.5 & 2.4 & 1.9 & 1.6 & \\
\hline 4 Primary deficit & -3.0 & 4.7 & 3.3 & 4.8 & 4.6 & 3.9 & 2.9 & 0.5 & -0.1 & -0.9 & -0.9 & \\
\hline \multirow{2}{*}{$\begin{array}{l}\text { Revenue and grants } \\
\text { Primary (noninterest) expenditure }\end{array}$} & 47.1 & 48.6 & 50.6 & 52.6 & 52.3 & 51.5 & 52.1 & 53.8 & 54.3 & 55.0 & 55.0 & \\
\hline & 44.1 & 53.3 & 53.9 & 57.4 & 56.9 & 55.4 & 54.9 & 54.3 & 54.2 & 54.1 & 54.0 & \\
\hline 7 Automatic debt dynamics $2 /$ & 1.1 & 0.5 & 0.5 & 0.6 & 1.4 & 7.4 & 5.1 & 2.0 & 2.5 & 2.8 & 2.6 & \\
\hline \multirow{2}{*}{$\begin{array}{l}\text { Contribution from interest rate/growth differential } 3 / \\
\text { Of which contribution from real interest rate }\end{array}$} & 1.1 & 0.5 & 0.5 & 0.6 & 1.4 & 7.4 & 5.1 & 2.0 & 2.5 & 2.8 & 2.6 & \\
\hline & 4.8 & 3.5 & 3.4 & 2.9 & 0.8 & 5.0 & 5.9 & 5.3 & 5.5 & 5.8 & 5.7 & \\
\hline Of which contribution from real GDP growth & -3.7 & -3.0 & -2.9 & -2.3 & 0.6 & 2.4 & -0.9 & -3.3 & -3.0 & -3.0 & -3.1 & \\
\hline \multirow{2}{*}{$\begin{array}{l}1 \text { Contribution from exchange rate depreciation 4/ } \\
2 \text { Other identified debt-creating flows }\end{array}$} & 0.0 & 0.0 & 0.0 & 0.0 & 0.0 & & & $\ldots$ & $\ldots$ & $\ldots$ & & \\
\hline & 0.0 & 0.0 & 0.0 & 0.0 & 0.0 & 0.0 & 0.0 & 0.0 & 0.0 & 0.0 & 0.0 & \\
\hline Privatization receipts (negative) & 0.0 & 0.0 & 0.0 & 0.0 & 0.0 & 0.0 & 0.0 & 0.0 & 0.0 & 0.0 & 0.0 & \\
\hline Recognition of implicit or contingent liabilities & 0.0 & 0.0 & 0.0 & 0.0 & 0.0 & 0.0 & 0.0 & 0.0 & 0.0 & 0.0 & 0.0 & \\
\hline $5 \quad$ Other (specify, e.g. bank recapitalization) & 0.0 & 0.0 & 0.0 & 0.0 & 0.0 & 0.0 & 0.0 & 0.0 & 0.0 & 0.0 & 0.0 & \\
\hline 6 Residual, including asset changes $(2-3) 5 /$ & 4.0 & 1.4 & -1.4 & 1.7 & -3.4 & -2.2 & 0.0 & 0.0 & 0.0 & 0.0 & 0.0 & \\
\hline Public sector debt-to-revenue ratio $1 /$ & 185.0 & 193.0 & 190.4 & 196.4 & 202.7 & 223.6 & 236.2 & 233.1 & 235.5 & 236.0 & 239.0 & \\
\hline \multirow{2}{*}{$\begin{array}{l}\text { Gross financing need } 6 / \\
\text { in billions of U.S. dollars }\end{array}$} & 14.3 & 23.3 & 21.0 & 22.4 & 24.0 & 24.4 & 23.7 & 19.0 & 18.5 & 18.0 & 17.9 & \\
\hline & 0.4 & 0.7 & 0.7 & 0.8 & 0.9 & 0.9 & 0.9 & 0.7 & 0.8 & 0.8 & 0.8 & \\
\hline \multirow{2}{*}{$\begin{array}{l}\text { Scenario with key variables at their historical averages } 7 / \\
\text { Scenario with no policy change (constant primary balance) in 2009-2014 }\end{array}$} & & & & & & 115.1 & 120.5 & 126.0 & 131.7 & 137.6 & 143.6 & 4.2 \\
\hline & & & & & & 115.1 & 124.1 & 130.0 & 136.5 & 143.4 & 150.2 & 3.0 \\
\hline \multicolumn{13}{|l|}{ Key Macroeconomic and Fiscal Assumptions Underlying Baseline } \\
\hline Real GDP growth (in percent) & 4.6 & 3.7 & 3.3 & 2.6 & -0.6 & -2.3 & 0.8 & 2.9 & 2.5 & 2.5 & 2.5 & \\
\hline Average nominal interest rate on public debt (in percent) $8 /$ & 6.5 & 7.2 & 7.0 & 7.7 & 6.5 & 5.6 & 6.7 & 7.2 & 7.2 & 7.2 & 7.2 & \\
\hline \multirow{2}{*}{$\begin{array}{l}\text { Average real interest rate (nominal rate minus change in GDP deflator, in percent) } \\
\text { Nominal appreciation (increase in US dollar value of local currency, in percent) }\end{array}$} & 6.0 & 4.4 & 4.0 & 3.3 & 0.8 & 4.6 & 5.3 & 4.7 & 4.7 & 4.8 & 4.7 & \\
\hline & 0.0 & 0.0 & 0.0 & 0.0 & 0.0 & & & & & & & \\
\hline $\begin{array}{l}\text { Inflation rate (GDP deflator, in percent) } \\
\text { Growth of real primary spending (deflated by GDP deflator in percent) }\end{array}$ & 0.5 & 2.7 & 3.0 & 4.4 & 5.7 & 1.0 & 1.4 & 2.5 & 2.5 & 2.4 & 2.5 & \\
\hline \multirow{2}{*}{$\begin{array}{l}\text { Growth of real primary spending (deflated by GDP deflator, in per } \\
\text { Primary deficit }\end{array}$} & -5.4 & 25.3 & 4.5 & 9.2 & -1.4 & -4.9 & 0.0 & 1.6 & 2.4 & 2.3 & 2.4 & \\
\hline & -3.0 & 4.7 & 3.3 & 4.8 & 4.6 & 3.9 & 2.9 & 0.5 & -0.1 & -0.9 & -0.9 & \\
\hline
\end{tabular}

$1 /$ Indicate coverage of public sector, e.g., general government or nonfinancial public sector. Also whether net or gross debt is used.

2/ Derived as $[(r-\pi(1+g)-g+\alpha \varepsilon(1+r)] /(1+g+\pi+g \pi))$ times previous period debt ratio, with $r=$ interest rate; $\pi=$ growth rate of GDP deflator; $g=$ real GDP growth rate; $\alpha=$ share of foreign-currency denominated debt; and $\varepsilon=$ nominal exchange rate depreciation (measured by increase in local currency value of U.S. dollar).

$3 /$ The real interest rate contribution is derived from the denominator in footnote $2 /$ as $r-\pi(1+g)$ and the real growth contribution as $-g$.

$4 /$ The exchange rate contribution is derived from the numerator in footnote $2 /$ as $\alpha \varepsilon(1+r)$

$5 /$ For projections, this line includes exchange rate changes.

/ Defined as public sector deficit, plus amortization of medium and long-term public sector debt, plus short-term debt at end of previous period.

7/ The key variables include real GDP growth; real interest rate; and primary balance in percent of GDP.

9/ Assumes that key variables (real GDP growth, real interest rate, and other identified debt-creating flows) remain at the level of the last projection year. 


\section{Appendix Figure 1. Barbados: Public Debt Sustainability: Bound Tests 1/}

(Baseline Scenario; Public debt in percent of GDP)
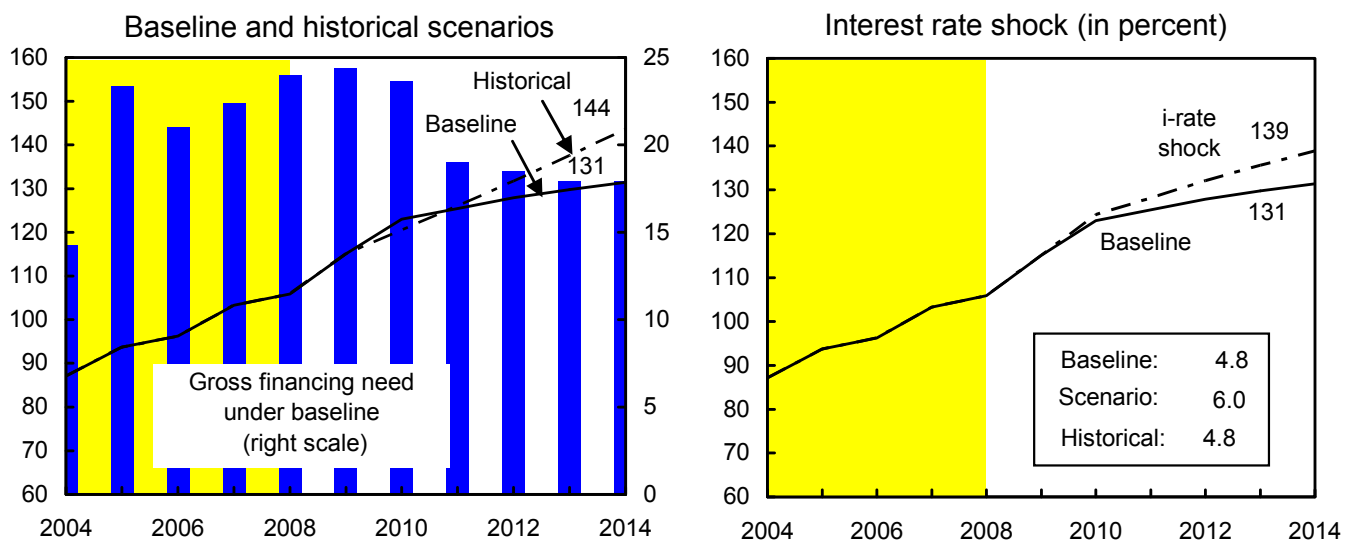

Growth shock (in percent per year)

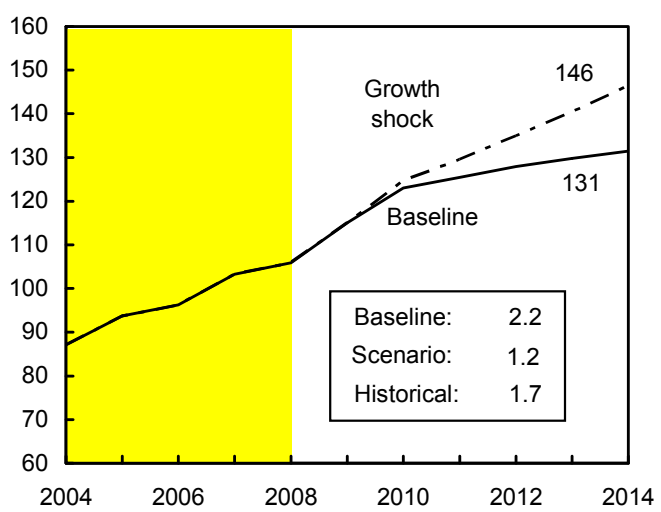

Primary balance shock (in percent of GDP) and no policy change scenario (constant primary balance)

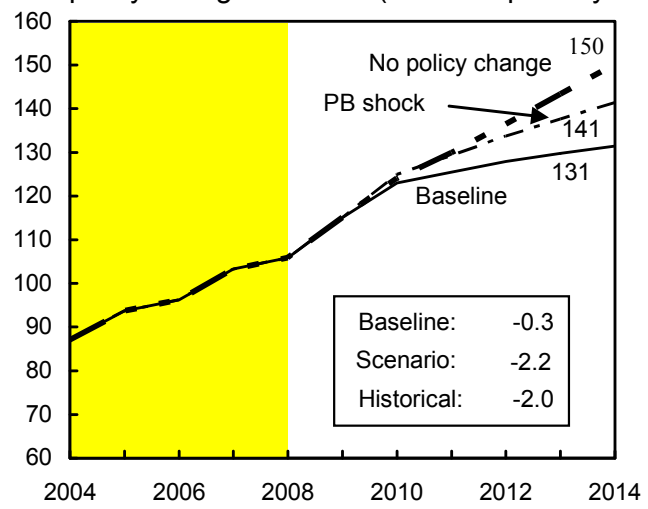

Combined shock 2/

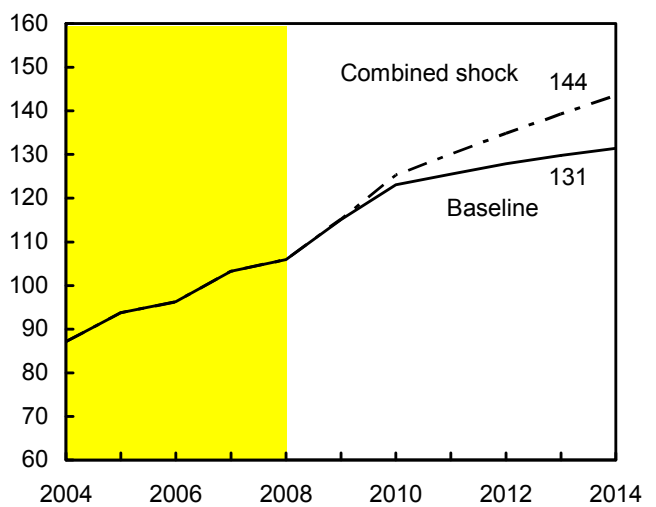

Real depreciation and contingent liabilities shocks $3 /$

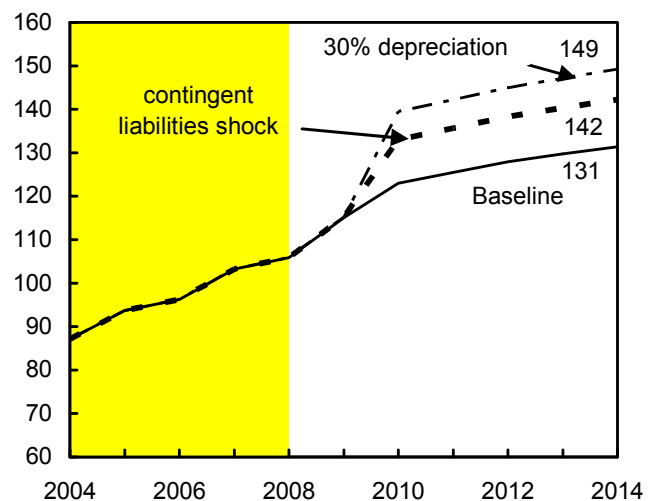

Sources: International Monetary Fund, country desk data, and staff estimates.

1/ Shaded areas represent actual data. Individual shocks are permanent one-half standard deviation shocks. Figures in the boxes represent average projections for the respective variables in the baseline and scenario being presented. Ten-year historical average for the variable is also shown.

2/ Permanent $1 / 4$ standard deviation shocks applied to real interest rate, growth rate, and primary balance.

$3 /$ One-time real depreciation of 30 percent and 10 percent of GDP shock to contingent liabilities occur in 2009, with real depreciation defined as nominal depreciation (measured by percentage fall in dollar value of local currency) minus domestic inflation (based on GDP deflator). 
Appendix Table 2. Barbados: External Debt Sustainability Framework, 2004-2014

(Baseline Scenario)

(In percent of GDP, unless otherwise indicated)

\begin{tabular}{|c|c|c|c|c|c|c|c|c|c|c|c|c|}
\hline & \multicolumn{5}{|c|}{ Actual } & \multicolumn{7}{|c|}{ Projections } \\
\hline & 2004 & 2005 & 2006 & 2007 & 2008 & 2009 & 2010 & 2011 & 2012 & 2013 & 2014 & Debt-stabilizing \\
\hline & & & & & & & & & & & & it account 6 / \\
\hline 1 Baseline: External debt & 39.5 & 41.3 & 44.3 & 46.5 & 47.4 & 50.3 & 49.0 & 46.8 & 44.4 & 42.1 & 40.2 & 1.8 \\
\hline 2 Change in external debt & -4.3 & 1.8 & 3.0 & 2.2 & 0.9 & 2.9 & -1.3 & -2.2 & -2.4 & -2.3 & -1.9 & \\
\hline 3 Identified external debt-creating flows $(4+8+9)$ & 8.9 & 8.6 & 2.7 & -4.3 & 2.0 & 5.5 & 4.9 & 3.3 & 3.4 & 3.4 & 3.3 & \\
\hline 4 Current account deficit, excluding interest payments & 9.6 & 9.1 & 4.4 & 0.9 & 5.3 & 0.6 & 0.8 & 0.6 & 0.5 & 0.5 & 0.3 & \\
\hline Deficit in balance of goods and services & 14.0 & 14.4 & 8.9 & 6.7 & 10.9 & 3.1 & 7.0 & 7.5 & 7.8 & 7.7 & 7.2 & \\
\hline Exports & 50.3 & 55.8 & 59.4 & 62.0 & 57.0 & 53.7 & 52.3 & 52.7 & 51.9 & 51.1 & 50.3 & \\
\hline Net non-debt creating capital inflows (negative) & -1.2 & -2.1 & -3.3 & -6.8 & -5.1 & -1.1 & -1.0 & -1.0 & -1.0 & -1.0 & -1.0 & \\
\hline Automatic debt dynamics $1 /$ & 0.5 & 1.6 & 1.6 & 1.7 & 1.9 & 6.0 & 5.1 & 3.7 & 3.9 & 4.0 & 4.0 & \\
\hline Contribution from nominal interest rate & 2.4 & 4.1 & 4.0 & 4.5 & 5.2 & 4.6 & 5.1 & 5.1 & 5.0 & 5.0 & 5.0 & \\
\hline Contribution from real GDP growth & -2.0 & -1.4 & -1.2 & -1.4 & -0.1 & 1.5 & 0.0 & -1.4 & -1.1 & -1.1 & -1.0 & \\
\hline $2 \quad$ Contribution from price and exchange rate changes $2 /$ & 0.1 & -1.0 & -1.2 & -1.4 & -3.2 & $\ldots$ & $\ldots$ & $\ldots$ & $\ldots$ & $\ldots$ & $\ldots$ & \\
\hline 13 Residual, incl. change in gross foreign assets $(2-3) 3 /$ & -13.3 & -6.8 & 0.3 & 6.5 & -1.1 & -2.6 & -6.2 & -5.5 & -5.8 & -5.7 & -5.2 & \\
\hline External debt-to-exports ratio (in percent) & 78.7 & 74.0 & 74.5 & 74.9 & 83.1 & 93.7 & 93.6 & 88.8 & 85.6 & 82.3 & 79.9 & \\
\hline $\begin{array}{l}\text { Gross external financing need (in billions of US dollars) } 4 / \\
\text { in percent of GDP }\end{array}$ & 0.4 & 0.4 & 0.3 & 0.2 & 0.4 & 0.2 & 0.3 & 0.3 & 0.3 & 0.3 & 0.3 & \\
\hline \multicolumn{2}{|l|}{ Scenario with key variables at their historical averages 5 / } & & & & & 50.3 & 47.4 & 45.7 & 43.5 & 41.2 & 39.2 & -1.9 \\
\hline \multicolumn{13}{|l|}{ Key Macroeconomic Assumptions Underlying Baseline } \\
\hline Real GDP growth (in percent) & 4.8 & 3.9 & 3.2 & 3.4 & 0.2 & -3.0 & 0.0 & 3.0 & 2.5 & 2.5 & 2.5 & \\
\hline \multirow{2}{*}{$\begin{array}{l}\text { GDP deflator in US dollars (change in percent) } \\
\text { Nominal external interest rate (in percent) }\end{array}$} & -0.2 & 2.7 & 2.9 & 3.3 & 7.4 & 1.0 & 1.0 & 2.5 & 2.5 & 2.3 & 2.5 & \\
\hline & 5.7 & 11.0 & 10.3 & 10.9 & 12.0 & 9.5 & 10.3 & 11.0 & 11.3 & 11.8 & 12.4 & \\
\hline Growth of exports (US dollar terms, in percent) & 5.8 & 18.4 & 13.1 & 11.5 & -1.1 & -7.8 & -1.5 & 6.3 & 3.5 & 3.5 & 3.4 & \\
\hline Growth of imports (US dollar terms, in percent) & 14.5 & 16.4 & 3.4 & 7.4 & 6.4 & -18.1 & 5.7 & 6.9 & 4.3 & 3.3 & 2.9 & \\
\hline \multirow{2}{*}{$\begin{array}{l}\text { Current account balance, excluding interest payments } \\
\text { Net non-debt creating capital inflows }\end{array}$} & -9.6 & -9.1 & -4.4 & -0.9 & -5.3 & -0.6 & -0.8 & -0.6 & -0.5 & -0.5 & -0.3 & \\
\hline & 1.2 & 2.1 & 3.3 & 6.8 & 5.1 & 1.1 & 1.0 & 1.0 & 1.0 & 1.0 & 1.0 & \\
\hline
\end{tabular}

$1 /$ Derived as $[r-g-\rho(1+g)+\varepsilon \alpha(1+r)] /(1+g+\rho+g \rho)$ times previous period debt stock, with $r=$ nominal effective interest rate on external debt; $\rho=$ change in domestic GDP deflator in US dollar terms, $g=$ real GDP growth rate, $\mathrm{e}=$ nominal appreciation (increase in dollar value of domestic currency), and $\mathrm{a}=$ share of domestic-currency denominated debt in total external debt.

2/ The contribution from price and exchange rate changes is defined as $[-\rho(1+g)+\varepsilon \alpha(1+r)] /(1+g+\rho+g \rho)$ times previous period debt stock. $\rho$ increases with an appreciating domestic currency $(\varepsilon>0)$ and rising inflation (based on GDP deflator).

3/ For projection, line includes the impact of price and exchange rate changes.

4/ Defined as current account deficit, plus amortization on medium- and long-term debt, plus short-term debt at end of previous period.

5/ The key variables include real GDP growth; nominal interest rate; dollar deflator growth; and both non-interest current account and non-debt inflows in percent of GDP.

6/ Long-run, constant balance that stabilizes the debt ratio assuming that key variables (real GDP growth, nominal interest rate, dollar deflator growth, and non-debt inflows in percent of GDP) remain at their levels of the last projection year. 
Appendix Figure 2. Barbados: External Debt Sustainability: Bound Tests 1/ (Baseline Scenario; External debt in percent of GDP)
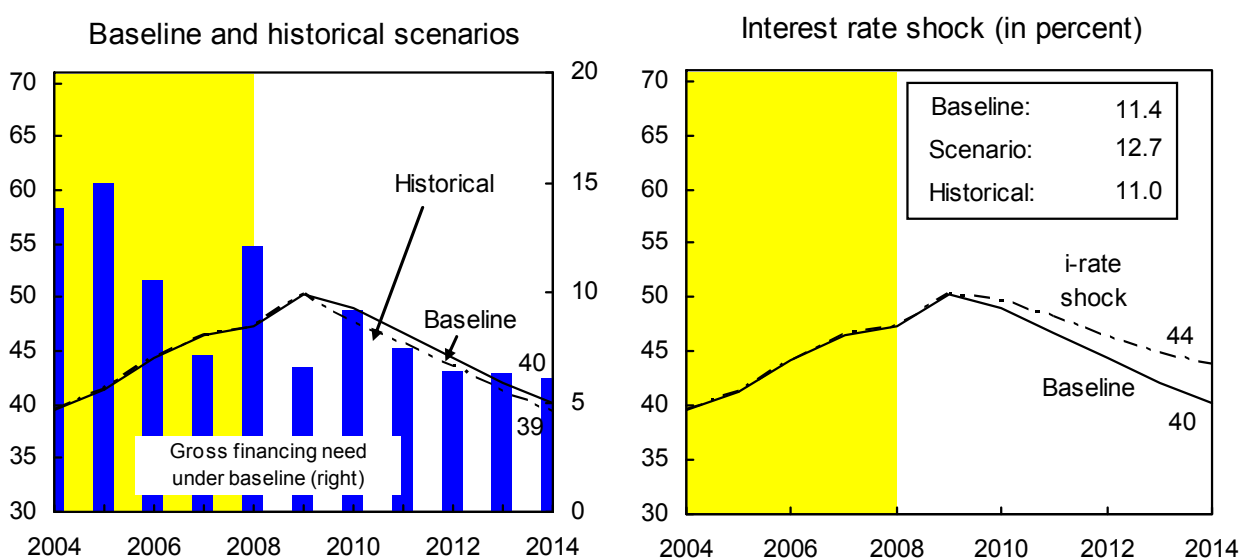

Growth shock (in percent per year)

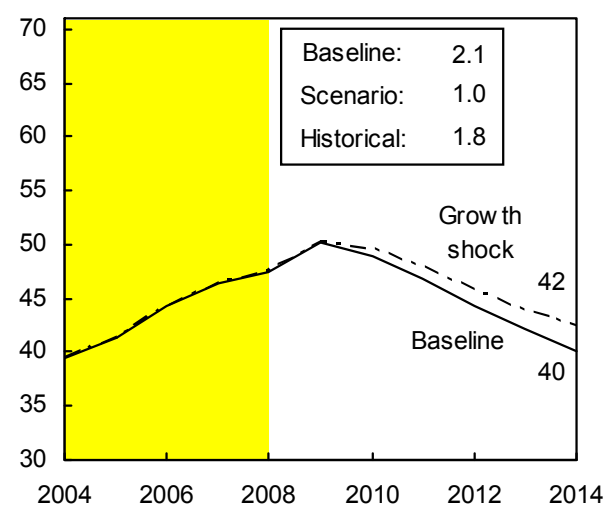

Non-interest current account shock (in percent of GDP)

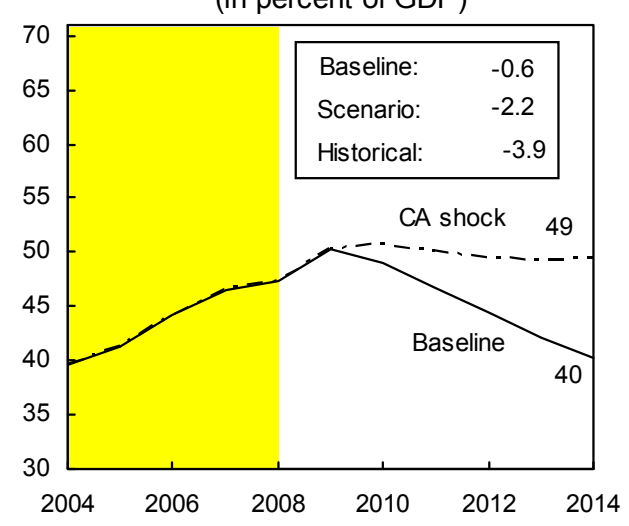

Combined shock 2/

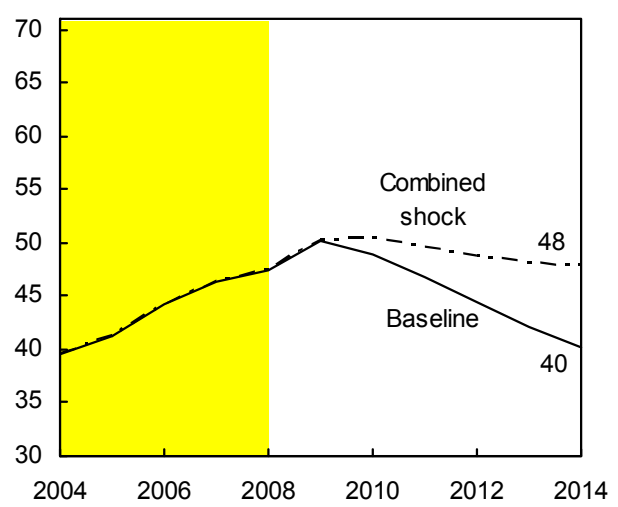

Real depreciation shock $3 /$

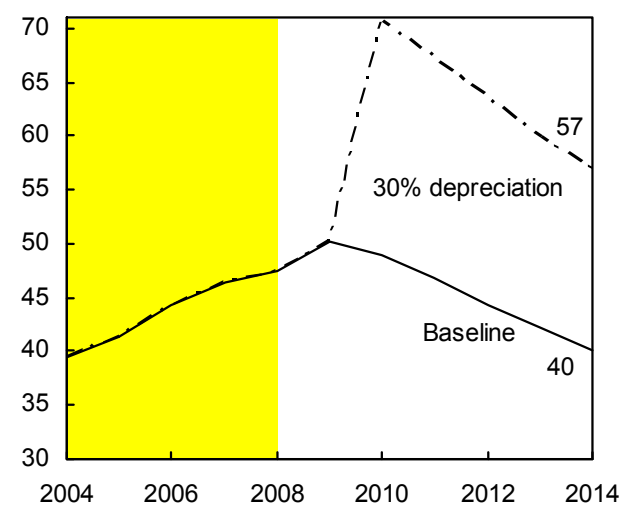

Sources: International Monetary Fund, Country desk data, and staff estimates.

$1 /$ Shaded areas represent actual data. Individual shocks are permanent one-half standard deviation shocks. Figures in the boxes represent average projections for the respective variables in the baseline and scenario being presented. Ten-year historical average for the variable is also shown.

2/ Permanent $1 / 4$ standard deviation shocks applied to real interest rate, growth rate, and current account balance.

3/ One-time real depreciation of 30 percent occurs in 2009. 
Appendix Table 3. Barbados: Public Sector Debt Sustainability Framework, 2004-2014 (Adjustment Scenario)

(In percent of GDP, unless otherwise indicated)

\begin{tabular}{|c|c|c|c|c|c|c|c|c|c|c|c|c|}
\hline & \multicolumn{5}{|c|}{ Actual } & \multicolumn{6}{|c|}{ Projections } & \multirow{3}{*}{$\begin{array}{c}\text { Debt-stabilizing } \\
\text { primary } \\
\text { balance } 9 /\end{array}$} \\
\hline & 2004 & 2005 & 2006 & 2007 & 2008 & 2009 & 2010 & 2011 & 2012 & 2013 & 2014 & \\
\hline \multirow{3}{*}{$\begin{array}{l}1 \text { Baseline: Public sector debt } 1 / \\
\text { Of which: foreign-currency denominated }\end{array}$} & & & & & & & & & & & & \\
\hline & 87.1 & 93.7 & 96.2 & 103.3 & 105.9 & 114.6 & 118.6 & 115.9 & 112.4 & 108.1 & 103.2 & 1.4 \\
\hline & 27.3 & 28.9 & 29.6 & 32.9 & 30.6 & 34.6 & 30.4 & 28.1 & 26.2 & 24.5 & 22.9 & \\
\hline & 2.2 & 6.6 & 2.5 & 7.0 & 2.7 & 8.7 & 4.0 & -2.7 & -3.5 & -4.3 & -4.9 & \\
\hline \multirow{2}{*}{$\begin{array}{l}3 \text { Identified debt-creating flows }(4+7+12) \\
4 \text { Primary deficit }\end{array}$} & -1.9 & 5.2 & 3.9 & 5.3 & 6.0 & 10.8 & 4.0 & -2.7 & -3.5 & -4.4 & -4.9 & \\
\hline & -3.0 & 4.7 & 3.3 & 4.8 & 4.6 & 3.0 & 0.0 & -2.9 & -4.4 & -5.7 & -6.4 & \\
\hline $5 \quad$ Revenue and grants & 47.1 & 48.6 & 50.6 & 52.6 & 52.3 & 51.6 & 52.5 & 53.7 & 54.4 & 54.9 & 55.1 & \\
\hline 6 Primary (noninterest) expenditure & 44.1 & 53.3 & 53.9 & 57.4 & 56.9 & 54.6 & 52.5 & 50.8 & 50.0 & 49.2 & 48.7 & \\
\hline 7 Automatic debt dynamics $2 /$ & 1.1 & 0.5 & 0.5 & 0.6 & 1.4 & 7.8 & 4.0 & 0.2 & 1.0 & 1.3 & 1.4 & \\
\hline 8 Contribution from interest rate/growth differential $3 /$ & 1.1 & 0.5 & 0.5 & 0.6 & 1.4 & 7.8 & 4.0 & 0.2 & 1.0 & 1.3 & 1.4 & \\
\hline Of which contribution from real interest rate & 4.8 & 3.5 & 3.4 & 2.9 & 0.8 & 5.0 & 5.7 & 4.9 & 4.7 & 4.7 & 4.5 & \\
\hline Of which contribution from real GDP growth & -3.7 & -3.0 & -2.9 & -2.3 & 0.6 & 2.8 & -1.7 & -4.7 & -3.7 & -3.4 & -3.1 & \\
\hline Contribution from exchange rate depreciation $4 /$ & 0.0 & 0.0 & 0.0 & 0.0 & 0.0 & & & & & $\ldots$ & $\ldots$ & \\
\hline 2 Other identified debt-creating flows & 0.0 & 0.0 & 0.0 & 0.0 & 0.0 & 0.0 & 0.0 & 0.0 & 0.0 & 0.0 & 0.0 & \\
\hline $3 \quad$ Privatization receipts (negative) & 0.0 & 0.0 & 0.0 & 0.0 & 0.0 & 0.0 & 0.0 & 0.0 & 0.0 & 0.0 & 0.0 & \\
\hline Recognition of implicit or contingent liabilities & 0.0 & 0.0 & 0.0 & 0.0 & 0.0 & 0.0 & 0.0 & 0.0 & 0.0 & 0.0 & 0.0 & \\
\hline $5 \quad$ Other (specify, e.g. bank recapitalization) & 0.0 & 0.0 & 0.0 & 0.0 & 0.0 & 0.0 & 0.0 & 0.0 & 0.0 & 0.0 & 0.0 & \\
\hline 6 Residual, including asset changes $(2-3) 5 /$ & 4.0 & 1.4 & -1.4 & 1.7 & -3.4 & -2.2 & 0.0 & 0.0 & 0.0 & 0.1 & 0.0 & \\
\hline Public sector debt-to-revenue ratio $1 /$ & 185.0 & 193.0 & 190.4 & 196.4 & 202.7 & 222.1 & 225.7 & 215.7 & 206.6 & 197.0 & 187.3 & \\
\hline \multirow{2}{*}{$\begin{array}{l}\text { Gross financing need } 6 / \\
\text { in billions of U.S. dollars }\end{array}$} & 14.3 & 23.3 & 21.0 & 22.4 & 24.0 & 23.6 & 20.5 & 15.0 & 13.1 & 11.7 & 10.7 & \\
\hline & 0.4 & 0.7 & 0.7 & 0.8 & 0.9 & 0.8 & 0.8 & 0.6 & 0.5 & 0.5 & 0.5 & \\
\hline \multirow{2}{*}{$\begin{array}{l}\text { Scenario with key variables at their historical averages } 71 \\
\text { Scenario with no policy change (constant primary balance) in 2009-2014 }\end{array}$} & & & & & & 114.6 & 120.0 & 125.5 & 131.2 & 137.1 & 143.1 & 4.2 \\
\hline & & & & & & 114.6 & 121.6 & 124.8 & 128.8 & 133.4 & 138.1 & 1.8 \\
\hline \multicolumn{13}{|l|}{ Key Macroeconomic and Fiscal Assumptions Underlying Baseline } \\
\hline Real GDP growth (in percent) & 4.6 & 3.7 & 3.3 & 2.6 & -0.6 & -2.6 & 1.5 & 4.2 & 3.4 & 3.2 & 3.0 & \\
\hline \multirow{3}{*}{$\begin{array}{l}\text { Average nominal interest rate on public debt (in percent) 8/ } \\
\text { Average real interest rate (nominal rate minus change in GDP deflator, in percent) } \\
\text { Nominal appreciation (increase in US dollar value of local currency, in percent) }\end{array}$} & 6.5 & 7.2 & 7.0 & 7.7 & 6.5 & 5.6 & 6.5 & 7.1 & 6.9 & 7.0 & 7.0 & \\
\hline & 6.0 & 4.4 & 4.0 & 3.3 & 0.8 & 4.6 & 5.2 & 4.6 & 4.4 & 4.5 & 4.5 & \\
\hline & 0.0 & 0.0 & 0.0 & 0.0 & 0.0 & & & & & & & \\
\hline \multirow{2}{*}{$\begin{array}{l}\text { Inflation rate (GDP deflator, in percent) } \\
\text { Growth of real primary spending (deflated by GDP deflator, in percent) }\end{array}$} & 0.5 & 2.7 & 3.0 & 4.4 & 5.7 & 1.0 & 1.4 & 2.5 & 2.5 & 2.5 & 2.5 & \\
\hline & -5.4 & 25.3 & 4.5 & 9.2 & -1.4 & -6.6 & -2.3 & 0.8 & 1.7 & 1.7 & 1.9 & \\
\hline Primary deficit & -3.0 & 4.7 & 3.3 & 4.8 & 4.6 & 3.0 & 0.0 & -2.9 & -4.4 & -5.7 & -6.4 & \\
\hline
\end{tabular}

$1 /$ Indicate coverage of public sector, e.g., general government or nonfinancial public sector. Also whether net or gross debt is used.

2/ Derived as $[(r-\pi(1+g)-g+\alpha \varepsilon(1+r)] /(1+g+\pi+g \pi))$ times previous period debt ratio, with $r=$ interest rate; $\pi=$ growth rate of GDP deflator; $g=$ real GDP growth rate; $\alpha=$ share of foreign-currency denominated debt, and $\varepsilon=$ nominal exchange rate depreciation (measured by increase in local currency value of U.S. dollar).

$3 /$ The real interest rate contribution is derived from the denominator in footnote $2 /$ as $r-\pi(1+g)$ and the real growth contribution as -9 .

$4 /$ The exchange rate contribution is derived from the numerator in footnote $2 /$ as $\alpha \varepsilon(1+r)$.

5/ For projections, his line includes exchange rate changes.

Tefined as public sector defict, plus amortization

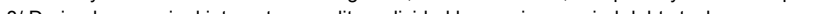




\section{Appendix Figure 3. Barbados: Public Debt Sustainability: Bound Tests 1/ (Adjustment Scenario; Public debt in percent of GDP)}
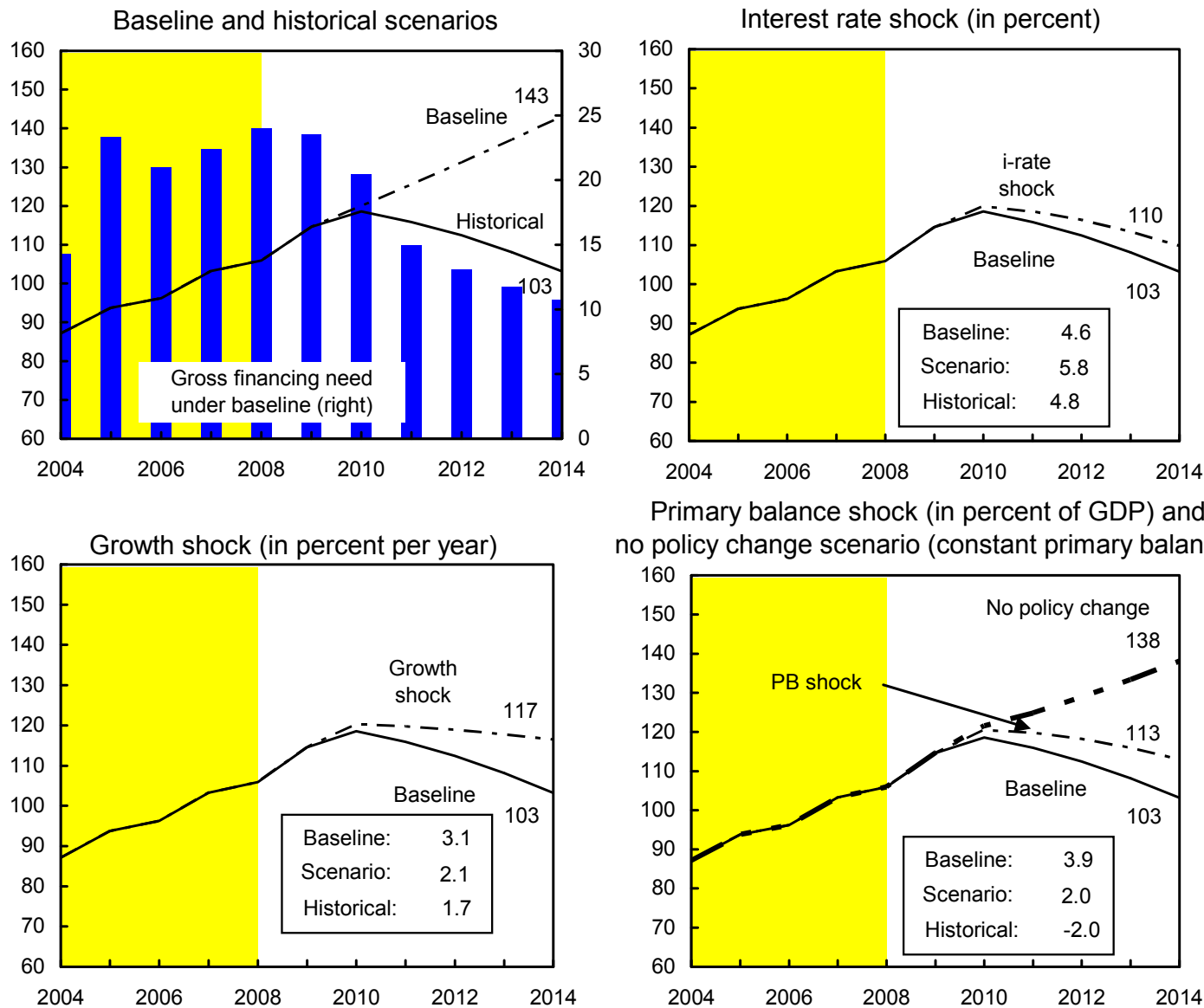

Primary balance shock (in percent of GDP) and no policy change scenario (constant primary balance)

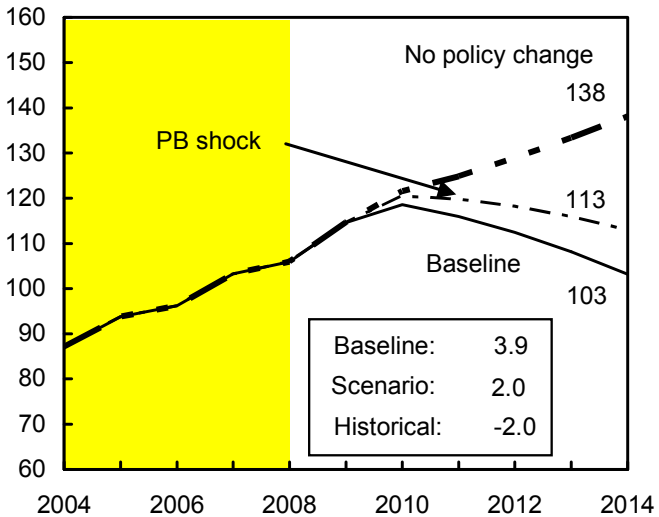

Combined shock 2/

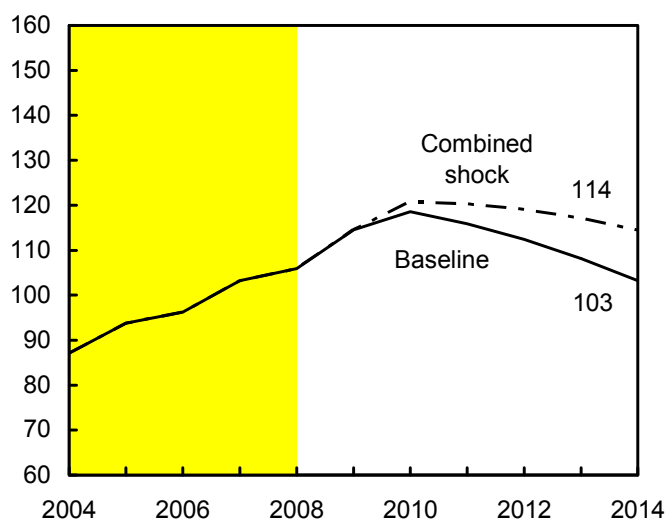

Real depreciation and contingent liabilities shocks 3/

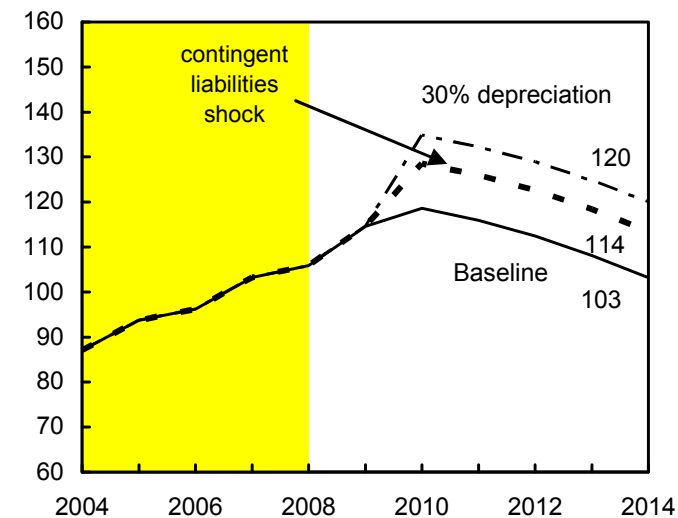

Sources: International Monetary Fund, country desk data, and staff estimates.

$1 /$ Shaded areas represent actual data. Individual shocks are permanent one-half standard deviation shocks. Figures in the boxes represent average projections for the respective variables in the baseline and scenario being presented. Ten-year historical average for the variable is also shown.

2/ Permanent $1 / 4$ standard deviation shocks applied to real interest rate, growth rate, and primary balance.

$3 /$ One-time real depreciation of 30 percent and 10 percent of GDP shock to contingent liabilities occur in 2009, with real depreciation defined as nominal depreciation (measured by percentage fall in dollar value of local currency) minus domestic inflation (based on GDP deflator). 
Appendix Table 4. Barbados: External Debt Sustainability Framework, 2004-2014

(Adjustment Scenario)

(In percent of GDP, unless otherwise indicated)

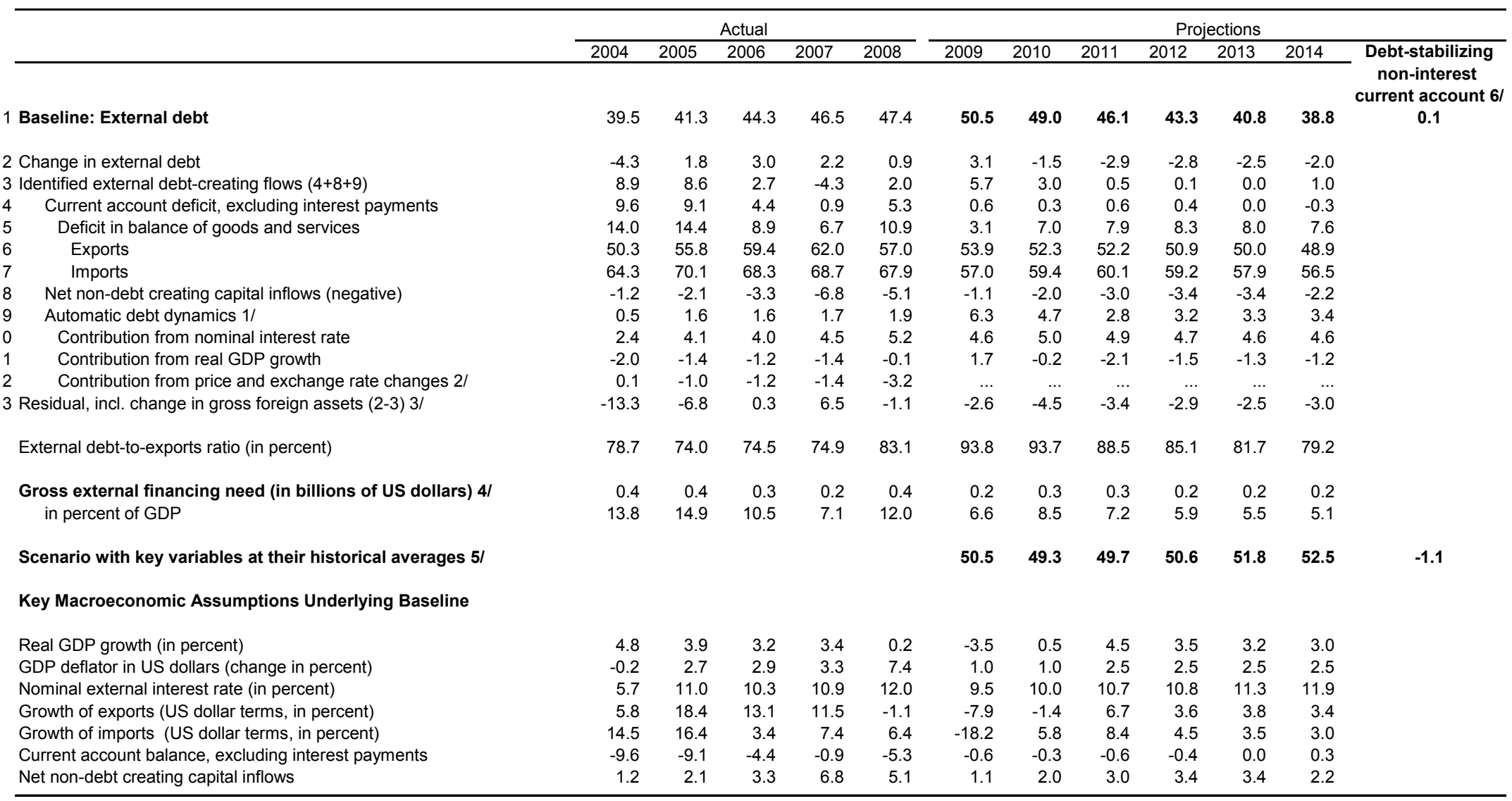

$1 /$ Derived as $[r-g-\rho(1+g)+\varepsilon \alpha(1+r)] /(1+g+\rho+g \rho)$ times previous period debt stock, with $r=$ nominal effective interest rate on external debt; $\rho=$ change in domestic GDP deflator in US dollar terms, $g=$ real GDP growth rate, $\mathrm{e}=$ nominal appreciation (increase in dollar value of domestic currency), and $\mathrm{a}=$ share of domestic-currency denominated debt in total external debt.

$2 /$ The contribution from price and exchange rate changes is defined as $[-\rho(1+g)+\varepsilon \alpha(1+r)] /(1+g+\rho+g \rho)$ times previous period debt stock. $\rho$ increases with an appreciating domestic currency $(\varepsilon>0)$ and rising inflation (based on GDP deflator).

3/ For projection, line includes the impact of price and exchange rate changes.

4/ Defined as current account deficit, plus amortization on medium- and long-term debt, plus short-term debt at end of previous period.

5/ The key variables include real GDP growth; nominal interest rate; dollar deflator growth; and both non-interest current account and non-debt inflows in percent of GDP.

6/ Long-run, constant balance that stabilizes the debt ratio assuming that key variables (real GDP growth, nominal interest rate, dollar deflator growth, and non-debt inflows in percent of GDP) remain at their levels of the last projection year. 
Appendix Figure 4. Barbados: External Debt Sustainability: Bound Tests 1/ (Adjustment Scenario; External debt in percent of GDP)
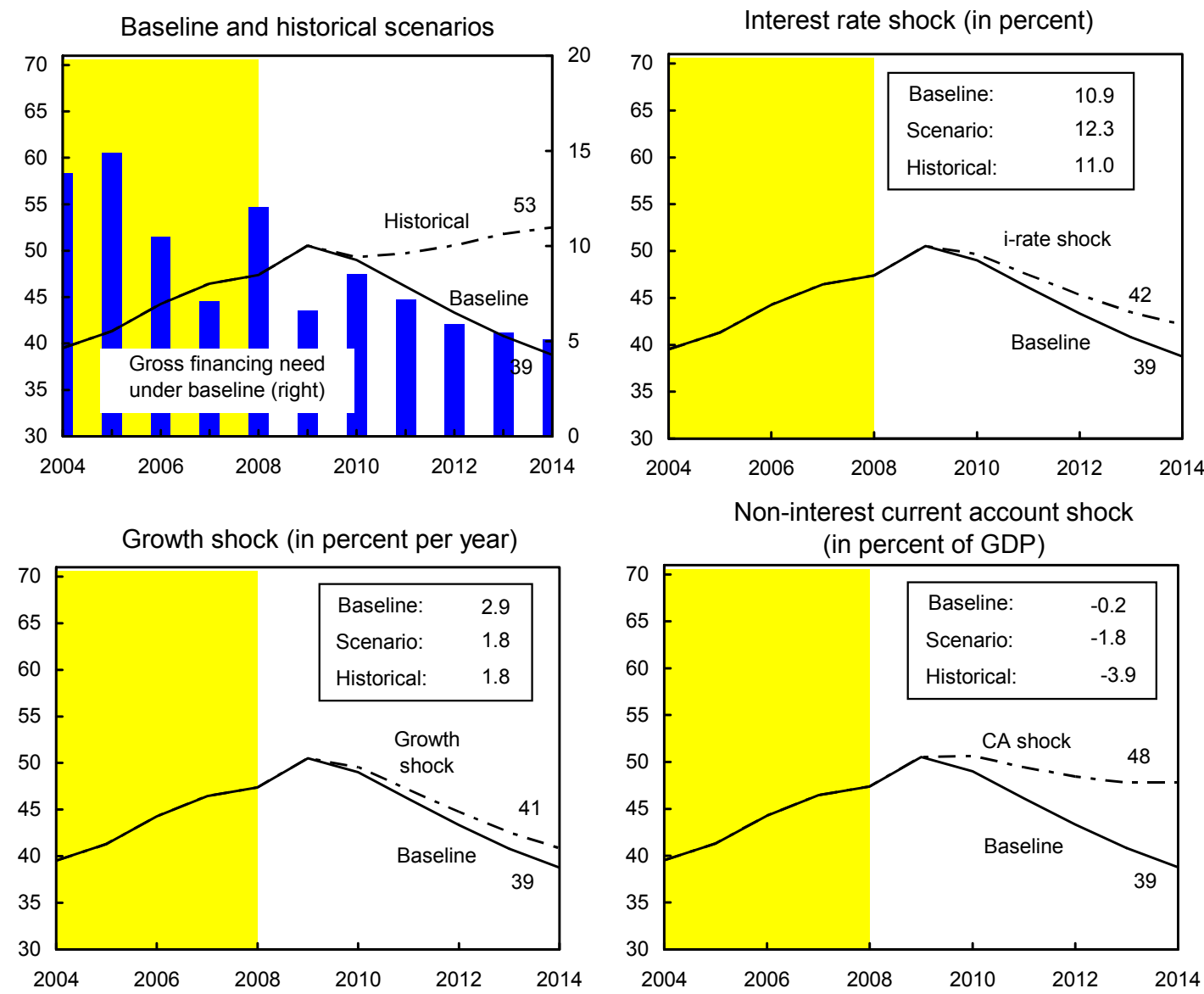

Combined shock 2/
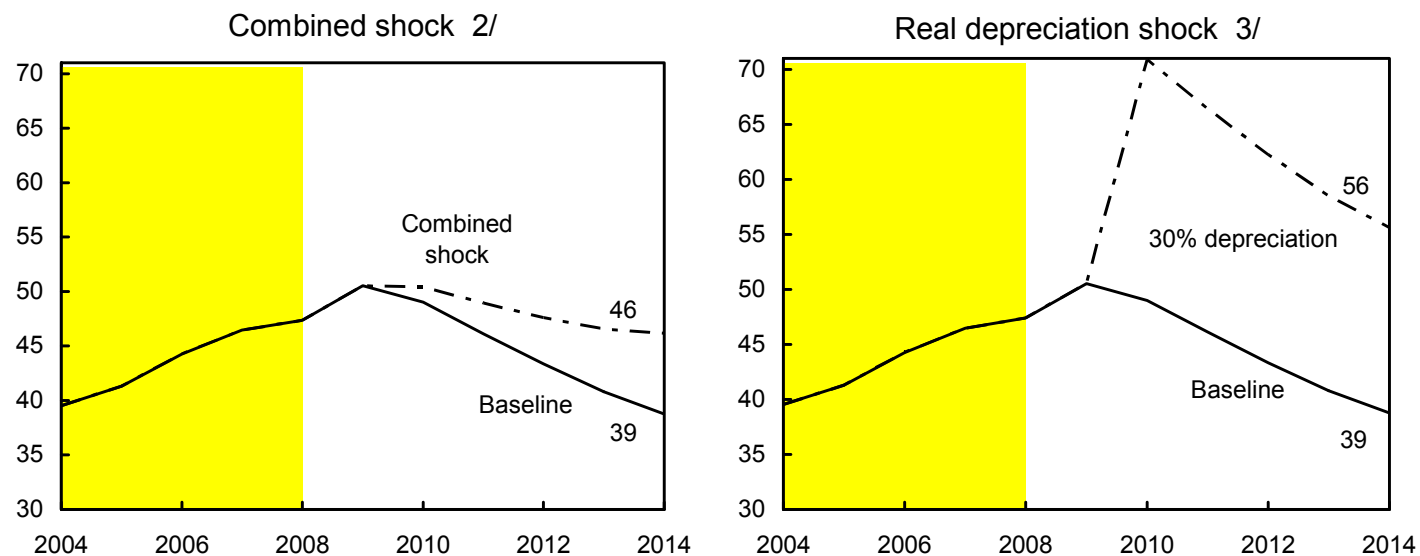

Sources: International Monetary Fund, Country desk data, and staff estimates.

$1 /$ Shaded areas represent actual data. Individual shocks are permanent one-half standard deviation shocks. Figures in the boxes represent average projections for the respective variables in the baseline and scenario being presented. Ten-year historical average for the variable is also shown.

2/ Permanent 1/4 standard deviation shocks applied to real interest rate, growth rate, and current account balance.

3/ One-time real depreciation of 30 percent occurs in 2009. 


\section{APPENDIX II. BACKGROUND AND SUMMARY OF APPENDICES}

Discussion. The 2009 Article IV consultation discussions were held in Barbados during July 10-17, 2009. The staff team comprised Trevor Alleyne (head), Gamal El-Masry, Usman Khosa, and Carla Macario (all WHD). Michael Horgan (Executive Director) and Pierre St-Amant (OED, Senior Advisor) participated in the concluding discussions. The team met with Prime Minister David Thompson; Minister of State (Finance) Senator Darcy Boyce; Central Bank Governor Dr. Marion Williams; other senior government officials; and representatives of the private sector and labor.

Exchange-rate arrangements Barbados accepted the obligations of Article VIII, Sections 2, 3, and 4 on November 3,1993, and there are no restrictions on the making of payments and transfers for current international transactions. The Barbados dollar has been pegged to the U.S. dollar since mid-1975 at BDS\$2.00 = US\$1.00.

\section{Fund relations.}

- Financial assistance. Barbados has no outstanding purchases and loans with the Fund. The last financial arrangement was a Stand-by Arrangement for the period 02/07/1992 to 05/31/1993 totaling SDR 23.9 million, of which SDR 14.7 million was drawn.

\section{- Recent technical assistance:}

$>$ CARTAC in July 2009 completed a three-year project of assisting the Barbados Statistics Services in improving the coverage, and revising the series, of current GDP data.

$>$ In July 2009, CARTAC and the IMF's Statistics Department conducted a workshop in Barbados on improving the coverage of government finance statistics.

$>$ In February 2009, a mission from the IMF's Statistics Department visited Barbados on monetary and financial statistics.

Relations with the World Bank Group. The World Bank just recently concluded an HIV/AIDS awareness and prevention project. A successor project, totaling US\$35 million, which became effective in 2009, is supporting the implementation of the 2008-2013 Barbados National HIV/AIDS Strategic Plan. More recently, the World Bank is also exploring whether it can resume policy-based lending to Barbados.

Relations with the Inter-American Development Bank (IADB). The IADB's Country Strategy with Barbados for the period 2005-08 focused on public sector reforms and improving competitiveness. The IADB is in the process of preparing a new successor Country Strategy with Barbados. The IADB's current Barbados portfolio totals US\$137 million, comprising US\$3 million in technical assistance grants and US\$134 million in investment loans.

Relations with the Caribbean Development Bank (CDB). Since 1970, the CDB has provided Barbados with loans and grants totaling US\$276 million in support of the productive sectors, economic infrastructure, health, and education. In 2008, the CBD disbursed loans amounting to US\$25.2 million to Barbados. Disbursements during the first five months of 2009 amounted to US\$4 million. 
INTERNATIONAL MONETARY FUND

BARBADOS

Staff Report for the 2009 Article IV Consultation-Informational Annex

Prepared by the Western Hemisphere Department

September 2, 2009

Contents

Page

Appendices

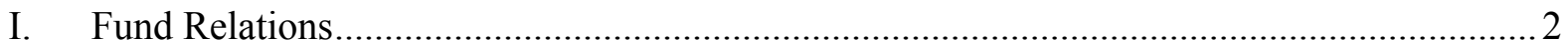

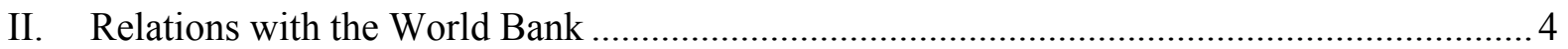

III. Relations with the Inter-American Development Bank ............................................... 5

IV. Relations with the Caribbean Development Bank........................................................... 7

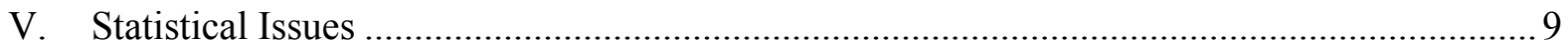


APPENDIX I. BARBADOS-FUND RELATIONS

As of June 31, 2009

I. Membership Status: Joined 12/29/1970; Article VIII

II. General Resources Account:

Quota

Fund holdings of currency

Reserve position in Fund

III. SDR Department:

Net cumulative allocation

Holdings
SDR million

67.50

61.92

5.71

SDR million

8.04

0.02
Percent

Quota

100.00

91.59

8.45

Percent of Allocation

100.00

0.25

IV. Outstanding Purchases and Loans: None

V. Financial Arrangements:

$\begin{array}{ccccc}\text { Type } & \begin{array}{c}\text { Approval } \\ \text { date }\end{array} & \begin{array}{c}\text { Expiration } \\ \text { date }\end{array} & \begin{array}{c}\text { Amount approved } \\ \text { (SDR million) }\end{array} & \begin{array}{c}\text { Amount drawn } \\ \text { (SDR million) }\end{array} \\ \text { Stand-by } & 02 / 07 / 1992 & 05 / 31 / 1993 & 23.89 & 14.67 \\ \text { Stand-by } & 10 / 01 / 1982 & 05 / 31 / 1984 & 31.88 & 31.88\end{array}$

\section{Projected Obligations to Fund}

(SDR million; based on existing use of resources and present holdings of SDRs):

\begin{tabular}{lcccc}
\multicolumn{5}{c}{ Forthcoming } \\
\hline 2009 & 2010 & 2011 & 2012 & 2013
\end{tabular}

Principal

Charges/Interest

$0.02 \quad 0.03$

$0.02 \quad 0.03$

0.03

0.03

0.03

0.03

Total

$$
0.02
$$

0.03

0.03

0.03

\section{Exchange Rate Arrangements:}

The Barbados dollar has been pegged to the U.S. dollar since mid-1975 at the rate of $\mathrm{BDS} \$ 2.00=\mathrm{US} \$ 1.00$. There are no restrictions on the making of payments and transfers for current international transactions subject to approval under Article VIII. There are exchange controls on some invisibles, but bona fide transactions are approved. All capital outflows and certain capital inflows require approval. The authorities accepted 
the obligations of Article VIII, Sections 2, 3, and 4 on November 3, 1993.

\section{Last Article IV Consultation}

The last Article IV consultation was concluded by the Executive Board on July 25, 2008; and the staff report was issued as IMF Country Report No. 08/295. Barbados is on the standard 12-month consultation cycle.

IX. Technical Assistance (2005-09):

$\begin{array}{lll}\text { Department } & \text { Dates } & \text { Purpose } \\ \text { CARTAC } & \text { 2006-2009 } & \begin{array}{l}\text { National accounts, revising current } \\ \text { GDP data }\end{array} \\ \text { CARTAC } & \text { April } 2009 & \begin{array}{l}\text { Government finance statistics } \\ \text { workshop }\end{array} \\ \text { STA } & \text { February } 2009 & \text { Monetary and financial statistics } \\ \text { CARTAC } & \text { Ongoing } & \text { Rebasing national accounts } \\ \text { FAD } & \text { March } 2008 & \begin{array}{l}\text { Administration of indirect } \\ \text { taxes and customs }\end{array} \\ \text { CARTAC } & \text { January } 2008 & \text { Revenue collection enforcement } \\ \text { STA } & \text { January } 2008 & \text { Monetary and financial statistics } \\ \text { STA } & \text { December } 2006 & \text { Monetary and financial statistics } \\ \text { STA } & \text { September } 2005 & \text { Multi-sector statistics advisor }\end{array}$

\section{Resident Representative:}

The resident representatives post was closed in January 1995. 


\section{APPENDIX II. BARBADOS-RELATIONS WITH THE WORLD BANK GROUP As of June 30, 2009}

1. The World Bank just recently concluded an HIV/AIDS awareness and prevention project. A successor program, Second HIV/AIDS Project (US\$35 million), which became effective in January 2009, is supporting the implementation of the 2008-2013 Barbados National HIV/AIDS Strategic Plan, specifically to promote: (i) adoption of safe behaviors, in particular amongst the most vulnerable groups; (ii) access to prevention, treatment and social care, in particular for the most vulnerable groups; (iii) capacity of organizational and institutional structures that govern the NAP; and (iv) use of quality data for problem identification, strategy definition and measuring results.

Summary of World Bank Loans, Credits, and Grants

(In millions of U.S. dollars)

\begin{tabular}{lrrrr}
\hline & IBRD & IDA Credits & IDA Grants & Total \\
\hline Original principal & 153.5 & 0.0 & 0.0 & 153.5 \\
Cancellations & 16.8 & 0.0 & 0.0 & 16.8 \\
Disbursed & 103.1 & 0.0 & 0.0 & 103.1 \\
Undisbursed & 33.4 & 0.0 & 0.0 & 33.4 \\
Repaid & 88.2 & 0.0 & 0.0 & 88.2 \\
Due & 15.0 & 0.0 & 0.0 & 15.0 \\
Exchange adjustment & 0.0 & 0.0 & 0.0 & 0.0 \\
Borrower obligation & 15.0 & 0.0 & 0.0 & 15.0 \\
\hline
\end{tabular}




\section{APPENDIX III. BARBADOS-RELATIONS WITH THE \\ INTER-AMERICAN DEVELOPMENT BANK}

As of July 31, 2009

The Inter-American Development Bank (IADB) has approved loans amounting to US\$400 million over the years of which US\$340 million have been disbursed, and with an undisbursed balance of US\$77 million. Net cash flow to Barbados has been negative since 2003 as a result of a slow-down in execution but a positive flow is projected in 2009 .

\section{Cash Flow Indicators}

\begin{tabular}{lcccccccccc}
\hline (US\$ million) & 2001 & $\mathbf{2 0 0 2}$ & $\mathbf{2 0 0 3}$ & $\mathbf{2 0 0 4}$ & $\mathbf{2 0 0 5}$ & $\mathbf{2 0 0 6}$ & $\mathbf{2 0 0 7}$ & $\mathbf{2 0 0 8}$ & $\mathbf{2 0 0 9 e}$ \\
\hline Loan approvals & 8.8 & 17.0 & 0.0 & 0.0 & 4.4 & 0.7 & 5 & 41.1 & 49.0 \\
Loan disbursements & 24.2 & 15.8 & 16.0 & 7.9 & 4.4 & 2.2 & 2.8 & 18.5 & 33.7 \\
Repayments & 7.9 & 8.1 & 11.0 & 13.8 & 12.2 & 15.6 & 15.9 & 19.7 & 20.4 \\
$\begin{array}{l}\text { Interest and } \\
\text { Commissions }\end{array}$ & 7.9 & 7.2 & 8.2 & 7.4 & 7.1 & 6.5 & 6.3 & 6.2 & 7.9 \\
Net cash flow & $\mathbf{8 . 4}$ & $\mathbf{0 . 5}$ & $\mathbf{- 3 . 2}$ & $\mathbf{- 1 3 . 3}$ & $\mathbf{- 1 4 . 9}$ & $\mathbf{- 1 9 . 9}$ & $\mathbf{- 1 9 . 4}$ & $\mathbf{- 7 . 4}$ & $\mathbf{5 . 4}$ \\
& & & & & & & & & \\
Debt outstanding & $\mathbf{1 4 3 . 9}$ & $\mathbf{1 5 1 . 6}$ & $\mathbf{1 5 6 . 6}$ & $\mathbf{1 5 0 . 7}$ & $\mathbf{1 5 0 . 1}$ & $\mathbf{1 4 0 . 6}$ & $\mathbf{1 3 3 . 0}$ & $\mathbf{1 4 9 . 1}$ & $\mathbf{1 5 7 . 6}$ \\
\hline
\end{tabular}

Note: The projections for 2009 exclude an emergency liquidity loan which the IADB has been discussing with the Barbados Government.

The IADB is in the process of preparing a new Country Strategy with Barbados, which it expects to approve this year. The current Country Strategy is focused upon the areas of public sector reform and competitiveness. The IADB's current loan portfolio for Barbados totals US\$137 million, of which US\$61.1 million have been disbursed. In addition, the technical cooperation portfolio amounts to US\$3 million, of which US\$0.9 million have been disbursed. 


\section{Current Loan Portfolio}

\begin{tabular}{|c|c|c|c|}
\hline \multirow{2}{*}{ Name } & \multirow{2}{*}{ Approval Date } & \multicolumn{2}{|c|}{ Amount in US\$ } \\
\hline & & Approved & Disbursed \\
\hline Education Sector Enhancement Program & 1998 & $60,034,063$ & $45,054,162$ \\
\hline Administration of Justice & 2001 & $8,750,000$ & $1,724,988$ \\
\hline Coastal Infrastructure Program & 2002 & $17,000,000$ & $10,363,301$ \\
\hline Modernization of Customs, Excise and VAT & 2005 & $4,400,000$ & 731,062 \\
\hline $\begin{array}{l}\text { Housing and Neighbourhood Upgrading } \\
\text { Programme (Project Prep. Facility) }\end{array}$ & 2006 & 688,000 & 180,443 \\
\hline $\begin{array}{l}\text { Modernization of the Barbados National } \\
\text { Standards System }\end{array}$ & December 2007 & $5,000,000$ & 264,440 \\
\hline $\begin{array}{l}\text { Housing and Neighbourhood Upgrading } \\
\text { Program - Phase I }\end{array}$ & January 2008 & $30,000,000$ & $1,500,000$ \\
\hline Modernization of the Barbados Statistical Service & July 2008 & $5,000,000$ & 0 \\
\hline $\begin{array}{l}\text { PEF:Agricultural Health and Food Safety Program } \\
\text { Preparation (Project Preparation Facility) }\end{array}$ & December 2008 & $1,092,000$ & 0 \\
\hline $\begin{array}{l}\text { Modernization of the Barbados National } \\
\text { Procurement System }\end{array}$ & December 2008 & $5,000,000$ & 0 \\
\hline Total & & $136,964,063$ & $59,818,396$ \\
\hline
\end{tabular}

In 2009 , loans amounting toUS $\$ 50$ million are scheduled for approval plus a possibleUS $\$ 100$ million in fast disbursing financing from the Liquidity Program for Growth Sustainability.

\section{Lending Program}

\begin{tabular}{lr}
\hline Lending Program 2009 (Public Sector) & $\begin{array}{r}\text { Amount } \\
\text { (in US\$ } \\
\text { millions) }\end{array}$ \\
\hline Agricultural Health and Food Safety & 10 \\
Competitiveness Program & 10 \\
Water and Wastewater System Upgrade (PPP) & 30 \\
Total & 50 \\
\hline
\end{tabular}




\section{APPENDIX IV. BARBADOS-RELATIONS WITH CARIBBEAN DEVELOPMENT BANK As of May 31, 2009}

The Caribbean Development Bank (CDB) approved US\$276.1 million (net) in loans, contingent loans, equity and grants to Barbados between 1970 and 2008. This represents 8.4 percent of total approvals to CDB's borrowing member countries.

Of the total funds approved US\$78.7 million or 28.5 percent were allocated to the productive sectors which comprise agriculture, manufacturing, tourism, and mining. Approximately US $\$ 45.5$ million or 16.5 percent of the total was allocated to the manufacturing sector, while tourism accounted forUS\$28.9 million, or 10.0 percent.

Economic infrastructure accounted for US $\$ 143.8$ million or 52.1 percent of approved funds. Of these funds, US\$88.1 million (31.9 percent) were allocated to the transportation, US $\$ 50.2$ million (18.2 percent) to the education, and US\$3.2 million (1.2 percent) to the health sectors.

Table 1

CDB Loans, Equity and Grants Approved (Net) to Barbados 1970- 2008

\begin{tabular}{lrr}
\hline Sector & US\$ million & Percent \\
\hline Productive sector & $\mathbf{7 8 . 7}$ & $\mathbf{2 8 . 5}$ \\
Agriculture & 4.2 & 1.5 \\
Manufacturing & 45.5 & 16.5 \\
Tourism & 28.9 & 10.5 \\
Minining & 0.1 & 0.0 \\
Economic infrastructure & $\mathbf{1 4 3 . 8}$ & $\mathbf{5 2 . 1}$ \\
Power and energy & 0.1 & 0.0 \\
Water & 0.8 & 0.3 \\
Transportation & 88.1 & 31.9 \\
Housing & 1.4 & 0.5 \\
Education & 50.2 & 18.2 \\
Health & 3.2 & 1.2 \\
Multisector & $\mathbf{5 3 . 9}$ & $\mathbf{1 9 . 5}$ \\
Total & $\mathbf{2 7 6 . 0}$ & $\mathbf{1 0 0 . 0}$ \\
\hline
\end{tabular}

Source: Caribbean Development Bank. 
Table 2

Approvals of Loans, Contingent Loans, Equity and Grants (Net) 2002 - May 2009

\begin{tabular}{|c|c|}
\hline & $\begin{array}{c}\text { Annual approvals } \\
\text { US\$ Millions }\end{array}$ \\
\hline 2002 & 15.0 \\
\hline 2003 & 13.5 \\
\hline 2004 & 0.1 \\
\hline 2005 & 0.1 \\
\hline 2006 & 24.4 \\
\hline 2007 & 32.7 \\
\hline 2008 & 0.1 \\
\hline 2009 (May) & 0.0 \\
\hline
\end{tabular}

Source: Caribbean Development Bank

Table 3

CDB - Disbursements and Undisbursed Balances to Barbados 2002 - 2009 (US\$ millions)

\begin{tabular}{|c|c|c|}
\hline & $\begin{array}{c}\text { Disbursements during } \\
\text { the year }\end{array}$ & $\begin{array}{c}\text { Undisbursed balance at } \\
\text { the end of the year }\end{array}$ \\
\hline 2002 & 3.8 & 79.7 \\
\hline 2003 & 17.2 & 56.1 \\
\hline 2004 & 19.9 & 47.5 \\
\hline 2005 & 8.6 & 62.2 \\
\hline 2006 & 9.3 & 71.3 \\
\hline 2007 & 23.6 & 47.2 \\
\hline 2008 & 25.2 & 43.2 \\
\hline 2009 (May) & 4.0 & \\
\hline
\end{tabular}

In order to provide a strategic focus to guide CDB's interventions in Barbados, CDB intends to prepare a Country Strategy Paper (CSP) outlining its overall intervention strategy for Barbados over the 2010 - 2013 period. The CSP will be consistent with GOB's own development objectives. 


\section{APPENDiX V. BARBADOS-STATISTICAL ISSUES}

1. While data provision has some shortcomings, it is broadly adequate for surveillance purposes. Barbados participates in the General Data Dissemination System, with metadata and the authorities' plans for improving the statistical base posted on the Fund's Dissemination Standards Bulletin Board.

\section{Real Sector}

2. The Barbados Statistical Services compiles national accounts statistics according to the 1968 SNA manual. A lack of current, reliable source data on nonsugar agriculture, private construction, and nontourism service activities affects production-based GDP estimates. To address some of the weaknesses in this area the authorities initiated a census of economic activity in June 2005. The census covered tourism, financial businesses, and transport and communications. Expenditure-based GDP estimates are derived from selected surveys; the household survey yields a reliable estimate of aggregate consumption, but the external trade and investment surveys suffer from certain weaknesses. Constant price GDP estimates, compiled by the Central Bank of Barbados (CBB), have an outdated 1974 base year; the authorities are currently updating the base year to 2000 in order to facilitate comparison within the Caribbean Community area. The authorities, with the assistance of CARTAC, recently completed a revision of the national accounts data, which revealed that current GDP over the past two decades was underestimated by 7-20 percent. Thus, these data shortcomings add some uncertainty to the GDP analyses and projections, as presented in the staff report.

3. Despite recent initiatives to update the consumer price index and the index of industrial production, potential misalignments in real estate prices are not addressed due to the absence of a systematic index of property prices. The consumer price index uses an expenditure basket for 1998-99 for its July 2001=100 series introduced in January 2002. The index of industrial production is based on the sectoral weights from 1982; the authorities are currently working towards rebasing the series to 1994. Since these outdated base years do not necessarily reflect the current structure of consumption and production, they possibly distort the derived price data.

\section{Government finance statistics}

4. Fairly comprehensive and up-to-date above-the-line data are available for the general government, but there is a lag in the reporting of transfers. As a result of the incomplete coverage of off-budget transactions, a discrepancy exists between the overall balance and financing data. Public enterprise data are not systematically and promptly reported to the Ministry of Finance, Investment, Telecommunications and Energy. Financial sector data on public sector net domestic borrowing usually cannot be fully reconciled with above-the-line fiscal data, partly because of limited availability of nonbank financial sector information. This reduces the degree of certainty about the actual fiscal position. The authorities introduced accrual accounting of public finance in April 2007. 


\section{Monetary and financial statistics}

5. While some weaknesses remain with respect to the overall quality, coverage, and timeliness of the monetary and financial statistics, they do not hinder Fund surveillance. The 2007 and 2008 STA missions found that the quality of monetary and financial statistics was compromised by various methodological problems, misclassifications, and the inconsistent application of residency criterion. The technical assistance missions recommended correcting a number of misclassifications of accounting data and assisted the CBB in compiling the standardized report forms (SRFs). The CBB has recently started compiling monetary statistics based on the SFRs, which include comprehensive detailed depository corporations' data.

\section{External sector statistics}

6. Lags in the compilation of merchandise trade data, and infrequent and incomplete information on the activities of the offshore sector, limit the timeliness of the external current account balance estimates. Estimates of the components of the external financial account need to be improved, including data on the net international investment position. 


\section{BARBADOS: TABLE OF COMMON INDICATORS REQUIRED FOR SURVEILLANCE}

As of July 31, 2009

\begin{tabular}{|c|c|c|c|c|c|}
\hline & $\begin{array}{c}\text { Date of latest } \\
\text { observation }\end{array}$ & $\begin{array}{r}\text { Date } \\
\text { received }\end{array}$ & $\begin{array}{r}\text { Frequency of } \\
\text { Data }^{7}\end{array}$ & $\begin{array}{c}\text { Frequency of } \\
\text { Reporting }\end{array}$ & $\begin{array}{r}\text { Frequency of } \\
\text { publication }^{7}\end{array}$ \\
\hline Exchange Rates & Fixed & & & & \\
\hline International Reserve Assets and Reserve Liabilities of the Monetary Authorities ${ }^{1}$ & $5 / 31 / 09$ & $7 / 10 / 09$ & $M$ & $\mathrm{M}$ & $\mathrm{W}$ \\
\hline Reserve/Base Money & $5 / 31 / 09$ & $7 / 10 / 09$ & $\mathrm{M}$ & $\mathrm{M}$ & $\mathrm{M}$ \\
\hline Broad Money & $4 / 30 / 09$ & $7 / 10 / 09$ & M & M & $\bar{M}$ \\
\hline Central Bank Balance Sheet & $5 / 31 / 09$ & $7 / 10 / 09$ & $\mathrm{M}$ & $\mathrm{M}$ & $\mathrm{M}$ \\
\hline Consolidated Balance Sheet of the Banking System & $4 / 30 / 09$ & $7 / 10 / 09$ & $\mathrm{M}$ & $\mathrm{M}$ & $\mathrm{M}$ \\
\hline Interest Rates $^{2}$ & $5 / 31 / 09$ & $7 / 10 / 09$ & $\mathrm{M}$ & M & M \\
\hline Consumer Price Index & $4 / 30 / 09$ & $7 / 10 / 09$ & $\mathrm{M}$ & $\mathrm{M}$ & $\mathrm{M}$ \\
\hline $\begin{array}{l}\text { Revenue, Expenditure, Balance and Composition of Financing }{ }^{3}-\text { General } \\
\text { Government }\end{array}$ & $6 / 30 / 09$ & $7 / 10 / 09$ & Q & Q & Q \\
\hline $\begin{array}{l}\text { Revenue, Expenditure, Balance and Composition of Financing }{ }^{3}-\text { Central } \\
\text { Government }\end{array}$ & $6 / 30 / 09$ & $7 / 10 / 09$ & Q & Q & Q \\
\hline Stocks of Central Government and Central Government-Guaranteed Debt ${ }^{5}$ & $3 / 31 / 09$ & $7 / 10 / 09$ & Q & Q & Q \\
\hline External Current Account Balance & $12 / 08$ & $7 / 10 / 09$ & $\mathrm{~A}$ & $\mathrm{~A}$ & $\mathrm{Q}$ \\
\hline Exports and Imports of Goods and Services & $12 / 08$ & $7 / 10 / 09$ & $\mathrm{~A}$ & $\mathrm{~A}$ & $\mathrm{M}$ \\
\hline GDP/GNP & 2008 & $7 / 10 / 09$ & $\mathrm{~A}$ & $\mathrm{~A}$ & Q \\
\hline Gross External Debt & $12 / 31 / 08$ & $7 / 10 / 09$ & $\mathrm{~A}$ & $\mathrm{~A}$ & $\mathrm{M}$ \\
\hline International Investment Position $^{6}$ & & & & & \\
\hline
\end{tabular}

${ }^{1}$ Includes reserve assets pledged or otherwise encumbered as well as net derivative positions.

${ }^{2}$ Both market-based and officially-determined, including discount rates, money market rates, rates on treasury bills, notes and bonds.

${ }^{3}$ Foreign, domestic bank, and domestic nonbank financing.

${ }^{4}$ The general government consists of the central government (budgetary funds, extra budgetary funds, and social security funds) and state and local governments.

${ }^{5}$ Including currency and maturity composition.

${ }^{6}$ Includes external gross financial asset and liability positions vis a vis nonresidents.

${ }^{7}$ Daily (D), Weekly (W), Monthly (M), Quarterly (Q), Annually (A); Irregular (I); Not Available (NA). 


\section{INTERNATIONAL MONETARY FUND}

Public Information Notice (PIN) No. 09/117

FOR IMMEDIATE RELEASE

September 14, 2009
International Monetary Fund

$70019^{\text {th }}$ Street, NW

Washington, D. C. 20431 USA

\section{IMF Executive Board Concludes 2009 Article IV Consultation with Barbados}

On September 10, 2009, the Executive Board of the International Monetary Fund (IMF) concluded the Article IV consultation with Barbados. ${ }^{1}$

\section{Background}

Barbados benefits from well-functioning institutions and social and political stability. The country has some of the highest social and competitiveness indicators in the region and enjoys investment-grade rating on its sovereign debt. Its low crime rate, well-educated work force, and attractive natural setting have helped make it a top destination for highend tourism and a prime location for offshore financial services and real estate investment. While the long-standing peg to the U.S. dollar has provided a positive effect on investment and growth, some vulnerabilities arise from the high level of public debt and continued fiscal imbalances.

The global recession is severely affecting the Barbadian economy. After barely growing in 2008, real GDP is expected to contract by 3 percent in 2009 and to remain virtually flat next year, on account of weak performances in the tourism and construction sectors. After peaking at 11.2 percent in September 2008, twelve-month inflation is projected to decline to 3-4 percent by end-2009. The external current account deficit would narrow from $10 \frac{1}{2}$ percent of GDP in 2008 to 51/4 percent in 2009, and remain below 6 percent in

\footnotetext{
${ }^{1}$ Under Article IV of the IMF's Articles of Agreement, the IMF holds bilateral discussions with members, usually every year. A staff team visits the country, collects economic and financial information, and discusses with officials the country's economic developments and policies. On return to headquarters, the staff prepares a report, which forms the basis for discussion by the Executive Board. At the conclusion of the discussion, the Managing Director, as Chairman of the Board, summarizes the views of Executive Directors, and this summary is transmitted to the country's authorities.
} 
2010. International reserves, which declined by almost US $\$ 100$ million in 2008 , are likely to broadly stabilize during 2009 , boosted by the recent placement abroad of a US $\$ 120$ million government bond and by SDR allocations of around US $\$ 90$ million. Reflecting a steady relaxation of fiscal policies, the nonfinancial public sector balance shifted from a small surplus in FY 2004/05 (April to March) to a deficit of 71/2 percent of GDP in FY 2008/09. Based on current policies, it is likely to widen to $81 / 2$ percent of GDP this fiscal year, raising the public debt ratio to 115 percent of GDP by year-end.

\section{Executive Board Assessment}

Executive Directors noted that Barbados is facing a severe economic recession. Output is contracting, as the global financial crisis has depressed tourism, brought Foreign Direct Investment (FDI) to a sudden stop, and weakened public finances. Consequently, unemployment has risen to double-digit level. While the underlying balance of payments is expected to remain weak, international reserves are expected to increase marginally in 2009, on account of the SDR allocations and the large government bond issue abroad.

Directors took note of the authorities' commitment to maintaining the fixed exchangerate peg. The longstanding peg to the U.S. dollar has been an effective nominal anchor, providing price stability with a positive effect on investment and growth. While various indicators suggest that the actual exchange rate is close to its equilibrium level, Directors observed that the current global shocks have put strains on the country's economy. In addition, possible changes in tax regulations abroad could adversely affect Barbados's offshore financial sector, which is an important source of foreign exchange.

Directors encouraged the authorities to develop a credible medium-term fiscal adjustment plan and start with its implementation, as soon as possible. They were of the view that, if left unchecked, the large fiscal deficits, combined with an uncertain foreign financing outlook, could result in a deterioration in investor confidence. A concerted adjustment effort was, therefore, crucial to countering such a risk, by reducing fiscal financing needs, supporting the balance of payments, and placing public debt on a firm downward path. This would also enhance growth, including by strengthening confidence and attracting higher investment. To this end, Directors encouraged the authorities to commit early on to decisive fiscal measures, particularly in the area of expenditure restraint. They considered that it would also be important to develop contingency plans, in the event that the economic recovery was delayed and fiscal pressures persisted. Directors, however, underscored that Barbados was well placed to take such bold action, given its established social partnership with a proven track record of reaching social consensus, particularly at difficult times.

Directors noted that monetary policy should be geared to ensuring price stability and protecting foreign reserves. They observed that existing capital controls gave the country some protection against disruptive and volatile capital movements, thereby 
providing the authorities some room to independently set interest rates. Given the recent decline in foreign reserves, Directors encouraged the authorities, in the context of their strong commitment to the peg, to monitor developments closely before easing monetary policy further.

Directors considered that Barbados's banks appeared to be well capitalized. Prudential indicators remained favorable, and Directors advised the authorities to carefully monitor the incipient rise in nonperforming loans, although they were still at a relatively low level. On banking supervision, Directors recommended that the authorities review the implementation of certain Basel II standards, particularly regarding the self regulation by commercial banks. They commended the authorities for moving ahead with implementing the recommendations of the 2008 Financial Sector Assessment Program Update, adding that quick and decisive action should be taken to resolve the problems of CLICO-Barbados. Directors also noted that there was a need to develop contingency plans, should the current approach of selling the subsidiaries of CLICO-Barbados to private investors prove unsuccessful. This would be important in order to mitigate any impact on the public finances, and protect the financial system and investor confidence.

Public Information Notices (PINs) form part of the IMF's efforts to promote transparency of the IMF's views and analysis of economic developments and policies. With the consent of the country (or countries) concerned, PINs are issued after Executive Board discussions of Article IV consultations with member countries, of its surveillance of developments at the regional level, of post-program monitoring, and of ex post assessments of member countries with longer-term program engagements. PINs are also issued after Executive Board discussions of general policy matters, unless otherwise decided by the Executive Board in a particular case. The staff report (use the free Adobe Acrobat Reader to view this pdf file) for the 2009 Article IV Consultation with Barbados is also available. 
Barbados: Selected Economic Indicators

\begin{tabular}{|c|c|c|c|c|c|c|}
\hline & \multirow[b]{2}{*}{2005} & \multirow[b]{2}{*}{2006} & \multirow[b]{2}{*}{2007} & \multirow{2}{*}{$\begin{array}{l}\text { Prel. } \\
2008\end{array}$} & \multicolumn{2}{|c|}{ Proj. } \\
\hline & & & & & 2009 & 2010 \\
\hline \multicolumn{7}{|l|}{ Output and prices } \\
\hline Real GDP & 3.9 & 3.2 & 3.4 & 0.2 & -3.0 & 0.0 \\
\hline Nominal GDP & 6.7 & 6.2 & 6.8 & 7.6 & -2.0 & 1.0 \\
\hline Consumer prices & 6.1 & 7.3 & 4.0 & 8.1 & 3.5 & 5.2 \\
\hline \multicolumn{7}{|l|}{ Money and credit } \\
\hline Net domestic assets & 14.1 & 14.2 & 9.4 & 13.7 & 3.0 & 9.5 \\
\hline Of which: private sector credit & 21.7 & 13.2 & 6.4 & 11.1 & -0.7 & 1.9 \\
\hline Broad money & 6.9 & 11.3 & 13.2 & 2.8 & 4.5 & 5.4 \\
\hline \multicolumn{7}{|l|}{ Public sector operations $1 /$} \\
\hline Overall balance & -6.9 & -5.3 & -8.0 & -7.6 & -8.4 & -7.1 \\
\hline Central government balance & -1.3 & -3.2 & -5.7 & -6.3 & -8.0 & -8.9 \\
\hline Off-budget activities & -3.0 & -4.9 & -3.9 & -2.6 & -0.5 & 0.0 \\
\hline National Insurance Scheme balance & 3.7 & 4.1 & 3.7 & 3.4 & 1.5 & 3.3 \\
\hline Public enterprises balance & -6.3 & -1.4 & -2.1 & -2.1 & -1.5 & -1.5 \\
\hline Primary balance & -3.2 & -1.5 & -3.4 & -3.4 & -4.6 & -2.4 \\
\hline Public sector debt $2 /$ & 93.7 & 96.2 & 103.3 & 105.9 & 115.1 & 123.0 \\
\hline \multicolumn{7}{|l|}{ External sector } \\
\hline External current account balance & -13.1 & -8.4 & -5.4 & -10.5 & -5.2 & -5.9 \\
\hline External debt $3 /$ & 28.9 & 29.6 & 32.9 & 30.6 & 34.4 & 30.5 \\
\hline Gross international reserves (in millions of U.S. dollars) & 618 & 597 & 774 & 678 & 707 & 616 \\
\hline \multicolumn{7}{|l|}{ Memorandum item: } \\
\hline Nominal GDP (in millions of Barbados dollars) & 6,010 & 6,382 & 6,819 & 7,338 & 7,191 & 7,263 \\
\hline
\end{tabular}

Sources: Barbadian authorities; and IMF staff estimates and projections.

1/ Fiscal year (April-March).

2/ Includes central government and government guaranteed debt.

$3 /$ Includes public sector and nonfinancial private sector debt; end of fiscal year. 